Portland State University

PDXScholar

\title{
Stable Isotope and Ancient DNA Analysis of Dog Remains From Cathlapotle (45CL1), a Contact-Era Site on the Lower Columbia River
}

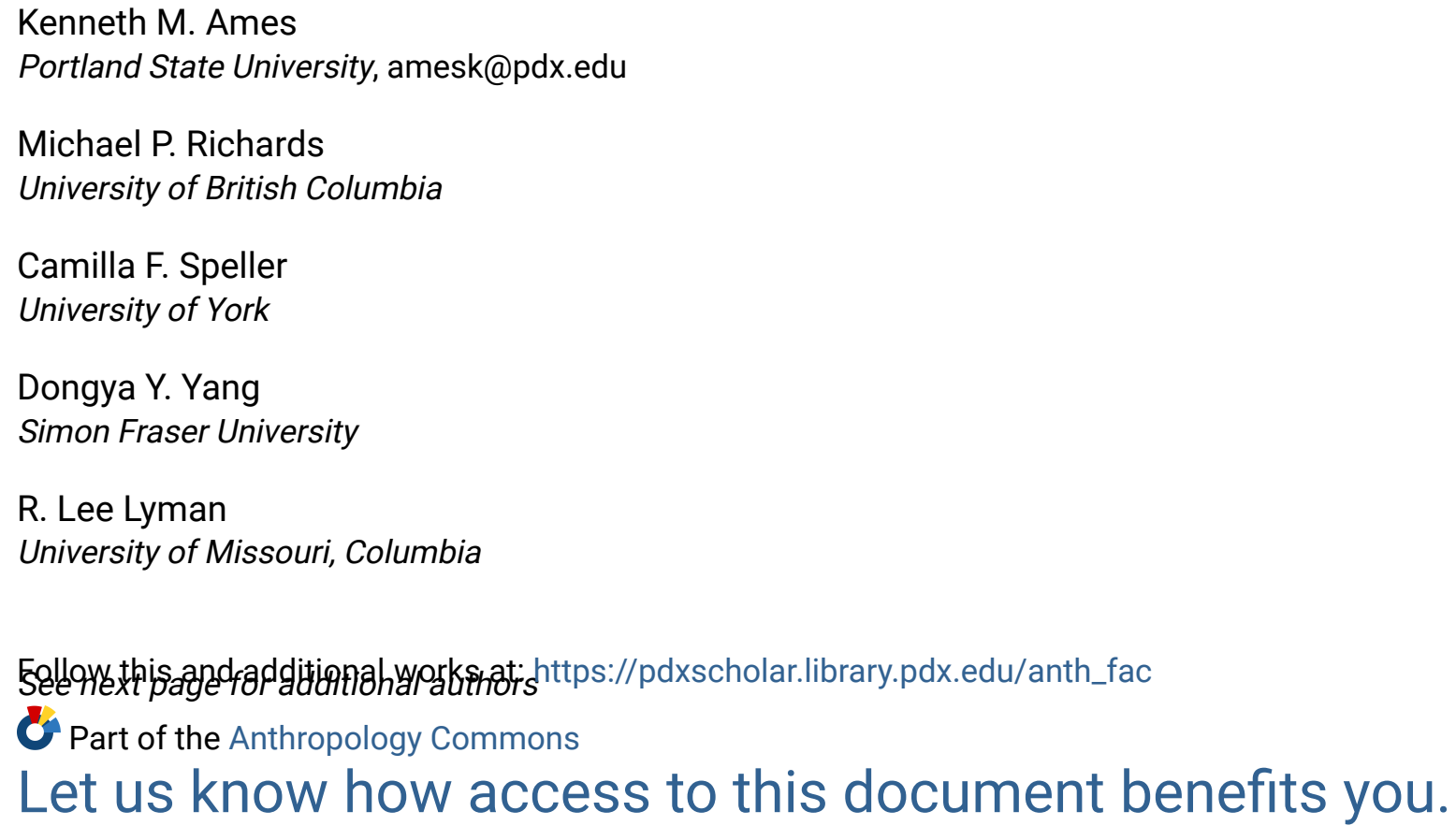

\section{Citation Details}

Ames, K. M., Richards, M. P., Speller, C. F., Yang, D. Y., Lyman, R. L., \& Butler, V. L. (2015). Stable isotope and ancient DNA analysis of dog remains from Cathlapotle (45CL1), a contact-era site on the Lower Columbia River. Journal of Archaeological Science, 57, 268-282.

This Post-Print is brought to you for free and open access. It has been accepted for inclusion in Anthropology Faculty Publications and Presentations by an authorized administrator of PDXScholar. Please contact us if we can make this document more accessible: pdxscholar@pdx.edu. 
Authors

Kenneth M. Ames, Michael P. Richards, Camilla F. Speller, Dongya Y. Yang, R. Lee Lyman, and Virginia L. Butler 


\section{Accepted Manuscript}

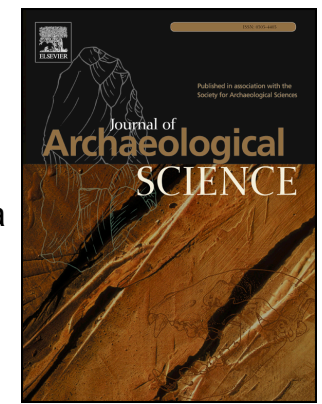

Stable isotope and ancient DNA analysis of dog remains from Cathlapotle (45CL1), a contact-era site on the Lower Columbia River

Kenneth M. Ames, Michael P. Richards, Camilla F. Speller, Dongya Y. Yang, R. Lee Lyman, Virginia L. Butler

PII: S0305-4403(15)00084-9

DOI: 10.1016/j.jas.2015.02.038

Reference: $\quad$ YJASC 4368

To appear in: Journal of Archaeological Science

Received Date: 25 June 2014

Revised Date: 25 February 2015

Accepted Date: 26 February 2015

Please cite this article as: Ames, K.M., Richards, M.P., Speller, C.F., Yang, D.Y., Lyman, R.L., Butler, V.L., Stable isotope and ancient DNA analysis of dog remains from Cathlapotle (45CL1), a contactera site on the Lower Columbia River, Journal of Archaeological Science (2015), doi: 10.1016/ j.jas.2015.02.038.

This is a PDF file of an unedited manuscript that has been accepted for publication. As a service to our customers we are providing this early version of the manuscript. The manuscript will undergo copyediting, typesetting, and review of the resulting proof before it is published in its final form. Please note that during the production process errors may be discovered which could affect the content, and all legal disclaimers that apply to the journal pertain. 
1 Stable isotope and ancient DNA analysis of dog remains from Cathlapotle

2 3

4 5

6

7

8

9

10

11

12 (45CL1), a contact-era site on the Lower Columbia River.

Kenneth M. Ames

Corresponding Author

Department of Anthropology

Portland State University

Portland Or 97207

amesk@pdx.edu

$\underline{503-725-3049}$

Michael P. Richards

Department of Anthropology

University of British Columbia

6303 NW Marine Drive

Vancouver, BC Canada V6T 1 Z1

Department of Human Evolution,

Max Planck Institute for Evolutionary Anthropology,

Deutscher Platz 6

04103 Leipzig Germany

Camilla F. Speller 
BioArCh, Department of Archaeology University of York

King's Manor, York, YO1 7EP, UK

$$
\text { Dongya Y.Yang }
$$

Department of Archaeology

Simon Fraser University

8888 University Drive

Burnaby, BC V5A 1S6, Canada

R. Lee Lyman

University of Missouri Columbia

Department of Anthropology

107 Swallow Hall

Columbia, MO 65211-0001

Virginia L. Butler

Department of Anthropology

Portland State University

Portland Or 97207

February 21, 2015 
45

46

47

48

49

50

51

52

53

54

55

56

57

58

59

60

\section{Abstract}

This study reports ancient DNA (aDNA) and stable isotope analyses of eight dog skeletal elements from the Cathlapotle site on the Lower Columbia River of the western United States. The aDNA analysis confirmed the elements as dogs (Canis lupus familiaris). Two haplotypes were found, both of which group within dog Clade A, and have patchy distributions to the north in British Columbia and as far south as Teotihuacan (Mexico). The isotopic analysis showed that the dogs' dietary protein was derived almost exclusively from marine sources. Lower Columbia River ethnohistoric accounts and Cathlapotle zooarchaeological records indicate that while marine fish were dietary keystones, the local diet was more diverse, and included terrestrial organisms and freshwater fishes. This apparent discrepancy raises the possibility the dogs were selectively fed. Thus their diet may not be a close proxy for human diet in this context.

Keywords: Northwest Coast, dogs, aDNA analysis, isotopes, diet. 
61 1. Introduction

62 There is a long standing debate among archaeologists in Cascadia, a portion of western North America encompassing the Northwest Coast, Intermontane Plateau and portions of the Subarctic (Figure 1), over whether the region's ancient economies were focal, even specialized, structured around a few keystone resources, especially salmon (Oncorhynchus spp.) and other marine resources, or whether they were built on multiple keystone resources. This debate emphasizes salmon fishing, which through intensification of harvesting and storage, is often viewed as the prime mover of social and cultural evolution in Cascadia (e.g. Matson and Coupland 1995, Hayden 1997).

Others hold that while salmon was a keystone economic resource, a diverse subsistence base was fundamental to supporting the area's large populations and complex social arrangements (e.g. Ames and Maschner 1999). FIGURE 1 ABOUT HERE.

This debate is difficult to resolve in part because the available evidence can be contradictory. On one hand, there is growing evidence for a diversified resource base. The salmon focus - what Monks (1987) called "salmonopia"- masks the importance of other marine fish such as herring (McKechnie et al. 2014) and cod (e.g. papers in Moss and Cannon 2011). There was significant modification of intertidal zones to manage and increase mollusk production, at least in some areas (e. g. Groesbeck et al. 2014) as well as management of terrestrial habitats for plant production (e.g. Deur and Turner

81 2005, Turner 2014). Some scholars (e.g. Campbell and Butler 2010) propose such 82 management extended to animals and fish. While recent studies of zooarchaeological 
records suggest that in a few places economies did focus narrowly on salmon (Coupland et al. 2010), more often they did not (Butler and Campbell 2004). Butler and Campbell reviewed zooarchaeological records in two study regions in southern Cascadia, one coastal and one in the interior, and found no evidence of intensification of salmon in either area during the last 7000 years, the period for which they had adequate samples. They measured intensification in two related ways: as specialization (narrowing diet breadth) and resource depression (declining prey abundance) (Butler and Campbell 2004: 337). While salmon were everywhere important, Butler and Campbell found evidence for diverse resource bases reflecting local conditions. On the other hand, stable isotopic evidence seems to point to a narrow, marine diet. Schwarcz et al. (2014), reviewing earlier published (Chisholm et al. 1983) and unpublished isotopic analyses of human remains from the British Columbia coast and interior, conclude protein sources were exclusively marine in origin and were primarily carnivorous fish and sea mammals. They see salmon as the principle resource. The virtual absence of terrestrial resources in their evidence leads them to postulate a dietary taboo on the coast against eating terrestrial animals, despite their exploitation for hides, bone etc. There is no ethnographic support for such a taboo. Human remains from the interior (a $100 \mathrm{~km}$ or more away from the coast) show a more mixed diet. We present the results of stable isotopic and aDNA analyses of dog remains from Cathlapotle (45CL1), a site located on the Lower Columbia River (LCR), in southwestern Washington State USA (Figure 1) dating between AD 1450 and ca. 1830 (Ames and Sobel 2009). Archaeological and ethnohistoric data (reviewed below) 
105 suggest a diverse diet with aquatic (marine, riverine, wet land) and terrestrial components. We compare the isotopic results to those of human and dog isotopic studies elsewhere on the Northwest Coast. aDNA analysis confirms the osteological identification of the canid elements used in the isotopic study as dog. We also compare the aDNA results with canids from Cascadia and North America. The study was originally undertaken to test a hypothesis that the salmon focus developed post-contact as a result of depopulation (Campbell 1991, Butler 2000) using stable isotopes. That test was not successful, for reasons discussed below, but it structured how samples were selected and that information is retained here. (e.g. Cannon et al. 1999, Tankersley and Koster 2009, Guiry 2012, 2013), although dog and human isotope values sometimes differ (Eriksson and Zagorska 2000, Bocherens et al. 2014, Tsutaya et al. 2014). When human remains are scarce or where cultural sensitivities regarding destructive testing of human remains exist, as they do in the LCR, dog remains provide a potentially useful way to track human diets. No stable isotope or aDNA analyses of human remains from the LCR or adjacent regions have

121 been accomplished to date nor are there human remains from Cathlapotle available for 122 such analysis were it possible. Our work focused on canid remains from well-defined, 123 pre-and post-contact depositional contexts. An underlying assumption of this and other

124 similar studies is that dogs essentially followed an encounter dietary strategy,

125 consuming the same animal products and in roughly the same proportions as did the 
126 humans with which they are associated (Guiry 2012, 2013) either directly or by eating

127 human feces (caecotrophy) (Tankersley and Koster 2010; Guiry 2012, Mack in press).

128 One of us (RLL) identified the remains as dog using morphology, which was

129 verified using aDNA analysis carried out by Simon Fraser University Ancient DNA

130 Laboratory. We wished to exclude the possibility that other canids such as $C$. latrans or

131 C. Iupus lupus were present in the sample. In addition, the DNA produced new

132 haplotype information for dogs in the LCR, which have not been explored to date.

\section{FIGURE 2 ABOUT HERE}

2. Background

Cathlapotle is located in the Wapato Valley (aka Portland Basin) portion of the

138 Lower Columbia River (LCR), the lowermost $320 \mathrm{~km}$ of the Columbia as it flows into the

139 Pacific Ocean (Figure 2). It is $11 \mathrm{~km}$ downriver from Vancouver, WA and Portland, OR.

140 The Wapato Valley encompasses the river's relatively broad floodplain and immediate

141 surrounding uplands between the Sandy and Cowlitz Rivers and contains the

142 metropolitan areas of Portland, OR and Vancouver, WA. The Columbia River was one

143 of the world's foremost rivers for Pacific salmon prior to extensive dam construction

144 after World War II. Salmon are anadromous, hatching in freshwater, moving

145 downstream to the ocean as immature fish, reaching maturity in the Pacific, and then

146 returning to their natal stream to spawn and die, sometimes in prodigious numbers. LCR

147 human populations were comparatively large and dense prior to contact and even after 
several major epidemics (Boyd 1999, 2013). Contact began c. 1774, with the first documented exploratory voyages along the coast (Hajda 1984; Gibson 1992; Ames and Maschner 1999). On-going contact began in 1792 with the European exploration of the Columbia River's mouth (Vancouver 1926), and the start of the maritime fur trade on the river (Gibson 1992; Igler 2004).

Cathlapotle was one of the largest and foremost Native American villages in the Wapato Valley (Figure 2). It was noted in multiple historic accounts (Sobel 2004). Lewis and Clark visited the village in 1806 (Moulton 1990). It is clear from these accounts that its people and chief(s) had ongoing and complex relationships with fur traders and other Europeans in the region. Located near the confluence of the Columbia River with four tributaries of differing sizes, its immediate hinterland included a diverse, fine grained patchwork of floodplain wetland, meadow and woodland habitats as well as closely adjacent upland plateaus.

The site was excavated over several field seasons in the 1990s by Portland State University under Ames' direction (Ames et al., 1999, Sobel, 2004, Smith, 2008). It is large $\left(15,000 \mathrm{~m}^{2} \times 2 \mathrm{~m}\right.$ deep), well stratified and contains six large depressions marking the locations of large wooden houses (Ames et al., 1999; 2008; Sobel, 2004; Smith, 2008; Shepard 2014). Chronological control is provided by 52 terrestrial radiocarbon dates (Ames and Sobel 2009) and a large, well stratified assemblage of fur-trade era trade goods. The site was occupied from AD 1450 until ca AD 1830 with very clearly distinguished pre-contact and post-contact era deposits (Ames and Sobel, 2009). The contact era at Cathlapotle begins in 1792 with the first recorded encounter between the 
170 townspeople and Europeans. Euro-american glass and ceramic trade goods (Kaehler,

171 2002; Cromwell, 2011) appear abruptly about $70 \mathrm{~cm}$ below surface. Pre-contact is the

172 period between AD 1450 and 1792 and is stratigraphically below the trade goods. The

173 post contact spans the time between 1792 and ca. 1830 and is represented by the

174 upper $70 \mathrm{~cm}$ or so of deposit. Overall, the site produced a rich assemblage of artifacts,

175 including faunal remains analyzed by Butler (2002, Butler and Martin 2013), Lyman

176 (2003), and Frederick (2009).

177 The Cathlapotle archaeofauna contained an NISP of 41 canids, 3 of which were

178 identified to the level of Canis lupus familiaris and 14 as Canis I. familiaris cf. None were

179 identified as either $C$. lupus or $C$. latrans. The sample used here was chosen from those

18017 elements. Eight of the 17 were post-contact in age, nine pre-contact in age. The

181 elements used were selected as much as possible from sheet midden deposits (Ames

182 et al. 1999) (Figure 3), which are well stratified with abrupt boundaries. They were also

183 selected to avoid sampling the same individual. These strictures produced the sample

184 of eight that we analyzed.

185 FIGURE 3 ABOUT HERE

186 The dog elements were not directly dated; we rely instead on stratigraphic

187 position, associated artifacts and associated terrestrial radiocarbon dates. The elements

188 were not radiometrically dated for two reasons: radiocarbon dates from ca. AD $1650-$

1891800 can produce high probability calibrations which may be as much as 100 or more

190 years off the sample's true age (Ames and Sobel 2009); and, assuming the dogs' diet

191 was wholly or in part marine in origin, a marine reservoir correction would be necessary 
192 for any calibration. Presently, there is no marine reservoir correction for the waters off

193 the mouth of the Columbia, nor a freshwater correction for the river itself. Consequently

194 any radiocarbon dates on the dog elements would have been difficult to interpret.

196 3. LCR and Cathlapotle subsistence, dogs and what they may have eaten.

As described in the documentary record, Lower Columbia River subsistence was, in Gahr's apropos phrasing (Gahr 2013, 64), a mix of resource diversity and focal resources. She describes the focal resources as keystone resources, which she identifies as cervids (deer [Odocoileus sp.] and wapiti, a.k.a. elk [Cervus elaphus]); berries, camas (Camassia quamash); wapato (Sagittaria latifolia) - these being exploited for their roots - and Western Red Cedar (Thuja plicata), used for industrial purposes. Her review did not include fish. In a parallel study using ethnohistoric accounts of fishing, Butler and Martin (2013) found four anadromous fish taxa to have been important. These taxa are: Salmonidae, most importantly the five species of Pacific salmon (Oncorhynchus sp.), especially Chinook salmon (O. tshawytscha); eulachon (Thaleichthys pacificus), a smelt; lamprey (Entosphenus sp.), especially Pacific lamprey (E. tridentate); and sturgeon (Acipenser sp.). Their review of fish archaeofaunas from the LCR (Butler and Martin 2013) indicates that salmon, eulachon

211 and sturgeon are widely abundant, but that some freshwater fish, including minnows

212 (Cyprinidae), suckers (Catostomidae), and Three spine stickleback (Gasterosteus 213 aculeatus) are also archaeologically abundant although virtually absent from 
214 documentary accounts. Butler and Martin (2013, 94 - 95) note that stickleback are a

215 traditional human and dog food in southwest Alaska. They also observe that fish bones

216 far outnumber mammal and bird bones in LCR archaeofaunas, pointing to the

217 importance of fish. This is certainly the case at Cathlapotle where fish bones are vastly

218 more common than mammal or avian bones, when NISP is standardized by sampled

219 deposit volume. The diversity in fish resources was compounded by local variability in

220 fish availability along the river resulting from a number of factors, making it difficult to

221 assign keystone status to any particular fish. Thus, the fifth keystone in LCR

222 subsistence is perhaps just fish.

223 The Cathlapotle mammalian archaeofauna (Lyman 2003), while diverse (Figure

224 4) (Supplemental Materials Table 1) as measured by taxonomic richness (Lyman,

225 2003), is dominated by cervid elements. Over $80 \%$ of the 6922 Number of Identified

226 Specimens (NISP) are deer and wapiti. The avian archaeofauna, while also diverse, is

227 dominated by water birds (Figure 4): ducks (Anas sp.) primarily, but some geese and

228 swans as well (Frederick, 2009). It is worth noting here that birds, as with the freshwater

229 fish discussed below, are not mentioned in the documentary record.

230 FIGURE 4 ABOUT HERE

231 The fish assemblage from Cathlapotle represents a diverse fauna (Figure 4),

232 including salmon and trout, sturgeon, and resident fresh-water fish, including the

233 minnows and suckers which were abundant in the wetland backwaters of the Wapato

234 Valley. Remains from the small-bodied eulachon and stickleback were prominent in fine

235 mesh samples. Pacific lamprey has not been identified in archaeological contexts, likely 
due to its cartilaginous skeleton (Butler and Martin, 2013). Potential sources of marine protein other than fish are rare in the Cathlapotle archaeofauna. Small numbers of harbor seal (Phoca vitulina, NISP $=65,<1 \%$ ) specimens are present in the mammalian archaeofauna (Lyman et al. 2002). There are no birds that are exclusively marine. Taken as a whole, the archaeofauna represents animals that inhabit marine systems at least during part of their life cycle, fully freshwater habitats, and terrestrial settings. available to them. However, there is little to no information in the documentary record on what they ate or were fed. Fur traders and other early European and American travelers, such as the Lewis and Clark expedition, commonly ate dogs but say nothing in their journals about what the dogs were fed (Mack i.p.). One factor that may have affected whether dogs were fed salmon (or restricted from eating it) and potentially other anadromous fish is so-called salmon-poisoning disease (SPD).

SPD is an infection by a bacterium - Neorickettsia helminthoeca - that as part of its life cycle can infect most of the anadromous fish of economic importance along the Lower Columbia (Headley et al. 2011, Table 1). The infection results from eating raw fish. SPD is known to infect 24 species of fish based either on direct observation in the field or experimental data (the fish are infected in a laboratory) (Headley et al. 2011). Among these are all five species of Pacific salmon, lamprey, sucker, minnows, and Three-spine stickleback. Missing from the list are eulachon and sturgeon. What is not discussed by Headley et al. (2011) is whether these are not susceptible or that no one 257 has investigated them. Salmon become infected in freshwater so presumably all of 
these other fish do. SPD is endemic to the Pacific coast from the Sacramento River north, including both in the USA and British Columbia because its life cycle requires a snail found only in this region. In the USA, its range extends inland from the coast to the western slopes of the Cascade mountain range. With the recent exception of southern Brazil, this is the only place in the world where it is known to occur. It was first reported in 1814 in northwest Oregon (Headley et al. 2011). Humans, dogs, foxes and coyotes as well as other mammals and birds are susceptible to it. The symptoms of infection are severe and death takes about 18 days after infection. Dogs sometimes survive. A Chinook scholar (Johnson, pers. comm.) discounts its importance for what local dogs ate, observing that dogs do survive and suspecting it would be impossible to keep them away from salmon scraps including viscera. Also, that choice pieces were reserved for people, and that these included often highly boney and cartilaginous cuts. He notes that dogs were, for cultural reasons, not allowed to eat salmon hearts. He also suggests that over time, local dogs would likely develop a resistance or immunity to the parasite as a consequence of natural selection. It is his view, based on inquiries elsewhere along the coast, that today dogs could not survive in indigenous settings without an immunity. The early reports of SPD are coincident with the arrival from elsewhere of dogs presumably without immunity.

At this point, regarding SPD, we are left with several alternatives: LCR dogs were immune; they were not immune, the immunity was partial; or fish were differentially infected. Since SPD occurs only on the Pacific Northwest, it is safe to assume it was not introduced along with other biological exotics during the fur trade. If the dogs were 
280 immune, the issue is moot. If they were not immune or partially immune, people either

281 tolerated a high death rate among dogs or managed their diets, keeping the dogs away

282 from infested fish. The fish may also have carried different disease loads. Of the fish at

283 issue here, salmon, lamprey and one species of minnow are demonstrated to carry it in

284 the wild; all the rest were infected experimentally. Perhaps they were not as subject to

285 infection in the wild. Regrettably, we do not have the epidemiological evidence with

286 which to evaluate these alternatives. Native testimony is clear their dogs are and were 287 immune.

288 Mack (i.p.) reviews the documentary evidence on the role of dogs in the LCR and

289 concludes they served as village watch dogs, companions, hunting partners (e.g.

290 Rollins 1935) and as "village sanitation specialists" - cleaning up human feces

291 (caecotrophy). As Guiry (2012) observes, while humans do not do this, dogs do, and the

292 effect of that difference on the use of dogs as a human dietary proxy is not well

293 understood. Following his advice, we can simply note this. The dogs probably also ate

294 butchery scraps, offal and bones. To the north, in the Salish Sea region of southern

295 British Columbia and northwestern Washington, two breeds of dogs existed, the regular

296 village dog and so-called wool dogs. "Village dogs" (Boyko and Boyko 2014, 186) are

297 the common dogs found world -wide that are "relatively free breeding and often times

298 partially free ranging" and scavenge at least some of their food. The dogs in this study

299 are presumably village dogs. Wool dogs were Spitz-like dogs whose fur was used in

300 weaving blankets (Schulting 1994, Crockford 1997, Crockford and Pye 1997, Solazzo et

301 al. 2011). Schulting (1994) suggests there is a faint possibility these dogs were kept on 
302

the LCR; Mack (i.p.) sees no evidence for wool dogs in the LCR. The breeds have been distinguished osteologically in the Salish Sea region (Crockford 1997). Schulting attempted to identify its hairs in a blanket using isotopic analysis. He argued that hairs present in the blanket with a strong marine signature were those of the wool dog, since the hairs from other potential sources, such as coyotes, would have a stronger terrestrial signal, as the dogs would have been fed or scavenged salmon.

\section{Expectations}

The available documentary and zooarchaeological evidence strongly indicates that the Chinookan peoples of the Lower Columbia River had a diverse diet harvested from a range of sources. Consequently their bone isotope signatures would not be as strongly marine as those reported for other Northwest Coast peoples (e.g. Schwarcz et al, 2014). Of course, stable isotopic data for humans are not available in the LCR nor are they likely to be in the foreseeable future. Assuming, as do most stable isotopic studies of dog diets, that the dogs were village dogs, and at least partially free-ranging and otherwise eating - either being fed or scavenging (Schulting 1994) - what the people ate, we would expect a more generalist signature for the dogs as well.

If salmon harvesting was intensified post-contact, as Butler (2000) hypothesized, our original empirical expectation was that this subsistence shift would be visible in the dogs' isotopic signatures by a rise in trophic level (as measured by $\delta{ }^{15} \mathrm{~N}$ ) as their diets became less diverse and trophically higher ranked as a consequence of consuming 
more salmon, a piscivore, and by an increase in the maritime contribution (indicated by relatively enriched $\delta{ }^{13} \mathrm{C}$ ) as the amount of dietary salmon increased.

Materials and Methods.

\section{1 aDNA analysis}

The eight canid samples from Cathlapotle identified as dog based on morphology were submitted to the dedicated Ancient DNA Laboratory at Simon Fraser University (SFU) (Table 1), which follows strict contamination control protocols, such as: separation of the pre-PCR (Polymerase Chain Reaction) and post-PCR work spaces; use of ancient DNA dedicated equipment; analysis of both positive and negative controls alongside the ancient DNA samples; and multiple extractions from the same sample in order to replicate the original results.

Samples were chemically decontaminated through submersion in a $6 \%$ sodium hypochlorite solution, followed by submersion in $1 \mathrm{~N} \mathrm{HCl}$ and $1 \mathrm{~N} \mathrm{NaOH}$, then rinsed in double distilled water. The bone samples were then UV irradiated for $60 \mathrm{~min}$, crushed into power and extracted following a silica-spin column method (Yang et al., 1998), modified following Speller et al. 2014.

Two pairs of published PCR primers were used to target two overlapping fragments of Canis mtDNA control region to produce a 345bp fragment: MitH52-DL: TCGAGGCATGGTGATTAAGCC /MitL63: ACCCCTACATTCATATATTGAATCACC) (Ishiguro et al., 2000), and DL-4 GCATATCACTTAGTCCAATAAGGG / DL-Hcanx 
CCTGAGGTAAGAACCAGATGCC) (Leonard et al., 2002). PCR amplifications were performed on an Eppendorf ${ }^{\mathrm{TM}}$ Mastercycler Personal Thermocycler using a $30 \mu \mathrm{L}$ reaction volume containing 1.5X Applied Biosystems ${ }^{\mathrm{TM}}$ Buffer, $0.3 \mu \mathrm{M}$ of each primer, 2 mM MgCl2, 0.2 mM dNTP, 1.0 mg/mL BSA, 3.0 $\mu \mathrm{L}$ DNA sample and $2.5 \cup$ AmpliTaq Gold LD (Applied Biosystems). Successfully amplified products were sequences using forward and reverse primers at the Macrogen Ltd. facility in Seoul, Korea. DG2 and DG4 underwent repeat extractions, and all samples were amplified at least twice to ensure the results were replicable. The ancient sequences were visually edited using ChromasPro software (www.technelysium.com.au), and sequences were truncated to $301 \mathrm{bp}$ once primer sequences were removed. Final sequences spanned region 15483-15783 of the $C$. familiaris reference mtDNA genome NC002008 (Kim et al. 1998). The obtained sequences were compared to Genbank sequences through the BLAST application to determine their closest match, and to ensure they did not match any other unexpected species or sequences. Haplotypes were assigned following Pereira et al. (2004). Multiple alignments of the ancient sequences and published canid reference sequences were conducted using ClustalW (Thompson et al. 1994), through BioEdit (Hall 1999). Phylogenetic comparisons with a subset of modern dog (Savolainen et al 2002) haplotypes from Genbank was conducted through Mega3 software (Kumar et al. 2004), using neighbor-joining through the Kimura 2-parameter. Additional comparisons of the 366 ancient haplotypes from Cathalpotle with other ancient hapotypes recovered from pre367 contact American archaeological sites (Leonard et al. 2002; Barta 2006; Brown et al. 
2013; Thalmann et al. 2013) were conducted though Network 4.6.1.2 (Bandelt et al. 1999).

\section{TABLE 1 ABOUT HERE}

\subsection{Isotopic analysis}

373 Five of the original eight Cathlapotle canid specimens (Table 2) were submitted to Beta Analytic for isotopic analysis; three specimens were consumed in the aDNA analysis. These three specimen were not replaced with additional ones because that would have significantly depleted the remaining nine Canis familiaris elements. Three of the surviving five elements were from post-contact deposits and two were from pre-contact contexts. In addition, to provide background isotopic values for possible prey items of

379 dogs and for carnivores and omnivores operating in the local environment, 12

380 archaeological remains from common animal taxa recorded at Cathlapotle were 381 analyzed: salmon, sturgeon, wapiti (elk), mallard, black bear (Ursus americanus), and raccoon (Procyon lotor). Black bear and raccoon were selected as dietary proxies for 383 dogs potentially provisioning themselves in local habitats. Raccoons have a highly 384 varied diet ranging from insects through amphibians to small birds (Maser et al. 1984).

385 Black bears are more omnivorous (Maser et al. 1984). Both would have been 386 encountered on the local floodplain. Neither is a perfect proxy but they are what was 387 available. There are no other canids, i.e. coyotes or wolves, identified in the 388 zooarchaeological assemblage to use for this purpose. After the Beta results were 389 returned, an additional 20 fish elements were submitted to the Isotope Laboratory at the 
390 Department of Human Evolution, Max Planck Institute for Evolutionary Anthropology in

391 Leipzig, Germany (Table 2) to expand the sample of fish and fish habitats. In addition to 392 salmon and sturgeon elements, these elements represented northern pikeminnow

393 (Ptychocheilus oregonensis), large scale sucker (Catostomus macrocheilus), and

394 eulachon, prominent in the fish fauna at Cathlapotle.

395 The procedures for collagen extraction and isotope measurement at the Beta

396 laboratories are described as follows (Hood, pers com): In the Beta Analytic laboratory,

397 the material was first tested for friability ("softness"). Very soft bone material is an

398 indication of the potential absence of the collagen fraction (basal bone protein acting as

399 a "reinforcing agent" within the crystalline apatite structure). It was then washed in de-

400 ionized water, the surface scraped free of the outer most layers and then gently

401 crushed. Dilute, cold $\mathrm{HCl}$ acid was repeatedly applied and replenished until the mineral

402 fraction (bone apatite) was eliminated. The collagen was then dissected and inspected

403 for rootlets. Any rootlets present were also removed when replenishing the acid

404 solutions. This was followed by additional pretreatment with sodium hydroxide $(\mathrm{NaOH})$

405 to ensure the absence of secondary organic acids. Beta Analytic did not provide

406 collagen criteria indicators such as the C:N ratio, \%C, \%N, or collagen yields. At the

407 Department of Anthropology, UBC (Vancouver, Canada) and at the Department of

408 Human Evolution in Leipzig, collagen was extracted from approximately $300 \mathrm{mg}$ of

409 whole bone, following the procedures outlined in Richards and Hedges (1999) with the

410 addition of an ultrafiltration step (Brown et al., 1988). Samples were demineralised in

$4110.5 \mathrm{M} \mathrm{HCl}$ at $5 \stackrel{\circ}{\circ}$ for 5 days, then rinsed in deionised water, the resultant solid 
412 gelatinised at $70{ }^{\circ} \mathrm{C}$ for 24 hours and then the solution filtered through $30 \mathrm{kDa}$

413 ultrafilters. Carbon and nitrogen isotope values were measured using a Thermo-

414 Finnigan Flash EA coupled to a Delta $\mathrm{V}$ isotope ratio mass spectrometer. All results had 415 acceptable C; $\mathrm{N}$ ratios (between 2.9 and 3.6, DeNiro 1986) and \%C and \%N values

416 (Ambrose, 1990) and the errors on the $\delta^{13} \mathrm{C}^{0} \% 0$ and $\delta^{15} \mathrm{~N} \%$ measurements are less than 0.2 per mil. TABLE 2 ABOUT HERE

Salmon was the only taxon successfully extracted and measured in both laboratories and the values are quite similar. Our salmon values are also close to those given by Szpak et al. (2009, Table 1) $\left(n=19\right.$, mean $\delta^{13} \mathrm{C}_{00}=-15.1 \pm 0.7$, mean $\delta^{15} \mathrm{~N} \%$

$421=12.2 \pm 0.8)$ and Scharcz et al. (2014, Table S3) $\left(n=4\right.$, mean $\delta^{13} \mathrm{C}^{0} / 00=-17.8 \pm 1.3$, mean $\left.422 \delta^{15} \mathrm{~N} \%=15.4 \pm 0.5\right)$. Therefore, we believe that the results from both laboratories are 423 comparable and we combine the data from both below. The absence of reported 424 collagen criteria indicators for the specimen analyzed by Beta Analytic that were not 425 duplicated could be seen as problematic, especially for the sturgeon, since efforts to replicate those results at the UBC laboratory had poor C:N. The reported sturgeon

427 values should consequently be viewed with caution. However, the results for the other 428 animals, most importantly the dogs, are consistent with, although not identical to, stable 429 isotope values reported elsewhere (e.g. Cannon et al. 1999, Grier 2006, Corr et al. 430 2009, Szpak et al.2009. Schwarzc et al. 2014) and we are confident of them.

$432 \quad$ 5. Results 


\section{$434 \quad 5.1 \quad$ aDNA}

435 Seven of the eight canid samples yielded amplifiable DNA (Table 1), resulting in two mitochondrial haplotypes detected in five and two individuals, respectively. Several criteria point to the authenticity of the sequences and rule out contamination from modern sources: 1) no PCR amplifications were observed in blank extracts and PCR negative controls; 2) the presence of two haplotypes within the samples as a whole, as well as within different extraction batches, minimizes the likelihood that they were from the same contamination source; 3) a subset of the sequences displayed characteristic damage patterns associated with degraded DNA (Brotherton et al. 2007, Gilbert et al. 2007); and 4) repeat extractions and/or repeat amplifications of all successfully amplified samples confirmed haplotype identifications.

According to the SFU lab protocols, species identification is assigned to a sample only if it matches identically or very closely with published reference sequences while

447 being clearly distinctive from the most closely related species and if no other evidence 448 including reproducibility tests or additional sequencing of the same sample indicates the 449 possibility of base pair ambiguities. Both haplotypes matched identically with Canis lupus familiaris reference sequences in Genbank (Table 1). Phylogenetic comparison of

451 the Cathlapotle sequences with modern canid reference sequences showed all the 452 aDNA sequences clustered together with those of modern dogs (Figure 5), differing 453 from the closely related coyote (Canis latrans). In addition to confirming the 454 identification of the canid specimens as dog, the aDNA analysis helps allay concerns 
about samples representing the same dog. The two samples recovered spatially closest together, samples DG3 and DG4, have different haplotypes.

Importantly, the aDNA analysis also provides additional mitochondrial haplotype data concerning ancient domestic dogs in Cascadia. Comparisons with previously published dog haplotypes indicated that ancient Cathlapotle sequences corresponded to Haplotype A3 $\left(15627,15639^{T / A}\right)$ as described by Savolainen et al. 2002, and Haplotype D25 $\left(15621,15639^{T / A}\right)$ as described by Vilà et al. 1997 (Table 1). When phylogenetically compared to other modern dog haplotypes, both haplotypes fall within the most diverse of the dog clades, Clade A (Savolainen et al. 2002), which includes a range of modern breeds from European, African, Indian, and American dogs, and is the most common lineage found in ancient North American dogs studied to date (Leonard et al., 2002; Brown et al. 2013; Barta 2006).

The two ancient haplotypes identified in this study match those recovered from other archaeological dog remains from the Americas (Figure 6). Haplotype A3 was detected in two archaeological sites on the Central Coast of British Columbia (Barta, 2006, 'hapC'): Namu (5 samples), and McNaughton Island (2 samples). A3 has also been detected in a 1,000 year old site in Florida as well as the ca. 8,500BP Koster site, in Illinois (Thalmann et al. 2013). The second haplotype, D25, has also been recovered from one archaeological individual each from Nitlitliquotlank on the Central Coast of British Columbia, Dionisio Point on Galiano Island in the Salish Sea, and T'ukw'aa on the west coast of Vancouver Island (Barta, 2006, 'Hapl') (Figure 1), as well as at Teotihaucan, Mexico dating to 1300 BP (Leonard et al., 2002). 


\section{FIGURE 5 ABOUT HERE}

\section{FIGURE 6 ABOUT HERE}

\subsection{Isotopic analysis}

The small sample size - five dogs - is a limitation, although it is equivalent to samples in other recently published studies (e.g. Byrd et al. 2013, Bocherens et al. 2014). Further, the close grouping of the isotopic values from dogs widely dispersed in time and space indicates the small sample size is not as serious a problem as it might be. The isotopic values of the pre and postcontact samples cluster tightly (Figure 7) while dogs from widely separated excavation units are also either identical or very similar in their values. For example, the two elements with virtually identical isotopic values, samples 4 and 6 , were recovered $2 \mathrm{~m}$ apart in depth from units $20 \mathrm{~m}$ distant and one is pre-contact (6) and the other postcontact (4) in age. The coherence of the results allows confidence in making inferences at the site level.

Isotope ratios for the potential dog dietary items from freshwater and terrestrial habitats are extremely distinct from dietary items with a marine life-phase (Table 2, Figure 7a). Carbon isotopes of the freshwater fish (minnows, suckers), terrestrial mammals, and ducks have much more depleted $\delta^{13} \mathrm{C} \%$ values (range: $-17.8 \delta^{13} \mathrm{C} \%$ to $-23.3 \delta^{13} \mathrm{C} \%$ ) than do the anadromous sturgeon, salmon and eulachon (range: -13.4 $\delta^{13} \mathrm{C} \%$ to $-15.9 \delta^{13} \mathrm{C} \%$ ). The relatively low $\delta^{13} \mathrm{C} \%$ values for the five dog specimens (range: $-14.1 \delta^{13} \mathrm{C}^{0} \mathrm{o}_{0}$ to $-15.1 \delta^{13} \mathrm{C} \%$ ) clearly indicate consumption of marine resources, which were the dominant protein source in their diets (Richards and Hedges 1999). 
Nitrogen isotopes also indicate the dogs mainly consumed creatures that spent

500 part of their life cycle at sea. The $\delta{ }^{15} \mathrm{~N} \%$ values for freshwater fish, ducks, and

501 mammals are consistently much lower (range: $3.8 \delta^{15} \mathrm{~N}^{0}$ o to $9.6 \delta^{15} \mathrm{~N} \%$ ) than those

502 for the anadromous fish (range: $13.0 \delta^{15} \mathrm{~N} \%$ oo to $16.4 \delta{ }^{15} \mathrm{~N} \%$ ); which show close

503 similarity to the $\operatorname{dog}{ }^{15} \mathrm{~N} \%$ values (range: $15.2 \delta{ }^{15} \mathrm{~N}_{00}$ to $17.2 \delta^{15} \mathrm{~N} / 00$ ). Since the

504 dogs' carbon and nitrogen isotope values are close to those for salmon, eulachon and

505 sturgeon (Figure 7b), it is clear they derived little protein from freshwater wetland or

506 upland habitats - i.e. they were not eating minnows, suckers or cervids to any

507 significant degree.

\section{FIGURE 7 ABOUT HERE.}

Two fish that could potentially have been important dietary items for which we do

510 not have isotopic values are the sticklebacks, which are well documented

511 zooarchaeologically at the site, and lamprey, which are documented in the ethnohistoric

512 record (Miller 2012, Butler and Martin 2013). Sticklebacks are freshwater fish that would

513 have been taken in backwater habitats so it is probable their isotopic signature would be

514 similar to the minnows and suckers we tested. It therefore seems unlikely then that the

515 dogs in our sample were eating them in any numbers. Lamprey, however, are

516 anadromous so their isotopic signature would presumably be similar to the anadromous

517 fish in our sample. Their skeleton lacks calcified structures and their absence from LCR

518 archaeofaunas is likely because of preservation biases (Butler and Martin 2013).

519 Which marine-anadromous taxa the dogs were eating is slightly less clear.

520 Predators are trophically a step above their prey and will be enriched in nitrogen relative 
521 to their prey. Predator - prey relationships are established using a stepwise offset

522 between isotopic values. A standard predator-prey nitrogen offset is $3.4 \%$ (e.g. Post,

523 2002; Minigawa and Wada, 1984). Carbon is more stable across trophic levels with very

524 small and variable offsets (Schoeninger and DeNiro, 1984; Fischer et al., 2007). We

525 useranges of $0-2 \%$ for carbon and $3-5 \%$ for nitrogen, following Bocherens and

526 Drucker (2003).Our data suggest the Cathlapotle dogs were primarily eating eulachon

527 of the anadromous fish that we tested. Their mean carbon values differ $(1.12 \%)$ more

528 than they do for salmon and sturgeon. The mean carbon values for the dogs, salmon

529 and sturgeon are very close $(-14.5 \%,-14.1 \%$ and $-13.8 \%$ respectively). The

530 differences (dog: salmon $-.4 \%$ and dog: sturgeon $-.7 \%$ ) are within the range of

531 potential measurement error and too small to be useful. The nitrogen data show an

532 offset of $2.5 \%$ between dogs and eulachon suggesting the dogs were eating eulachon,

533 perhaps some salmon but little sturgeon. It is also quite plausible they were eating

534 lamprey for which we do not have values. The mean nitrogen values for the dogs is 16.4

$535 \%, 16.4 \%$ for the sturgeon, and $14.5 \%$ for the salmon with differences of

536 dog:salmon of $1.86 \%$ and dog:sturgeon of $.0 \%$ again well within the range of

537 measurement error. Zooarchaeological data adds support to the inference that the dogs

538 were primarily eating eulachon. Eulachon elements constitute $56 \%$ of the fish NISP in

539 bulk samples collected at Cathlapotle (Table S3, Butler 2002). The village was close to

540 the Lewis River, which hosted a large eulachon run historically. Ethnohistoric accounts

541 (e.g. Boyd and Hajda 1987, Sobel 2004, Butler and Martin 2013) indicate eulachon

542 were taken and stored in prodigious amounts so the dried fish would have been 
543 available over much of the year. The issue of which fish the dogs were eating aside, it is

544 clear is that the dogs' isotopic values have a very strong marine signal and they were

545 not eating terrestrial or freshwater organisms. This is consistent with other stable

546 isotope analyses of Northwest Coast dogs (Cannon et al. 1999, Barta 2006, Grier

547 2006).

548 To put Cathlapotle in a larger context, we compared our isotope data to the

549 published records for dogs and human remains from other Cascadia archaeological

550 sites. Figure 7a compares the $\delta^{13} \mathrm{C} \%$ values for the Cathlapotle dogs to those for dogs

551 from the Namu (Barta, 2006; Cannon et al., 1999) and Keatley Creek (Barta, 2006)

552 archaeological sites; and to a sample of 38 human remains from Namu (Chisholm et al.,

553 1983, Schwarzc 2014, Table S1) and 16 human remains from 8 localities in interior

554 British Columbia (Schwarcz et al. 2014 Table S3). Namu is located on the central British

555 Columbia Coast and Keatley Creek is in the south-central interior plateau of British

556 Columbia (Figure 1) on the Thompson River, which supports a major salmon run. The

557 other 8 Interior localities are in the same general interior region and have salmon runs.

558 The closeness of the $\delta^{13} \mathrm{C} \%$ values for the Namu human and dog samples indicates

559 the dogs are good proxies for human diet, at least at Namu (Cannon et al. 1999). The

560 Namu zooarchaeological record also shows an overwhelming emphasis on marine

561 resources (Cannon, 1991). Barta (2006) suggests the relatively high $\delta^{13} \mathrm{C} \%$ values of

562 the Keatley Creek dogs reflects a mixed diet of salmon and terrestrial resources, given

563 Keatley Creek's interior location. We wonder whether the pattern may also reflect

564 salmon becoming more carbon depleted given that they stop eating as they ascend 
565

566

567

rivers in their runs. The Interior human remains (which do not include remains from Keatley Creek) display an even stronger mixed pattern, probably reflecting the diverse sources of the remains. The Cathlapotle dog's values are intermediate between Namu and Keatley Creek, suggesting they had more terrestrial foods than the Namu dogs but less than the Keatley dogs. However, the Cathlapotle dogs' isotopic values align very closely with the Cathlapotle salmon pointing to the possibility that their position on the graph vis a vis Namu may reflect some variation in isotopic values among North Pacific marine resources either through time (Misarti 2007) or among different species of salmon (Romanuk and Levings 2005) as much as it does variation in the proportion of marinelterrestrial resources in their diet. FIGURE 7 ABOUT HERE Whatever the Cathlapotle dogs were eating, they were all eating much the same thing, given how tightly their $\delta{ }^{13} \mathrm{C} \%$ values cluster. The spread of the Cathlapotle $\delta^{13} \mathrm{C} \%$ values is 1.4 $\%$. Keatley Creek's, with a comparable sample size, is $2.4 \%$, and with a much larger sample, Namu's spread is almost identical to Keatley Creek's at $2.3 \%$. The $\delta^{15} \mathrm{~N} \%$ values of the Namu, Keatley Creek and Cathlapotle dogs and the Namu and interior humans (Schwarzc 2014, Tables S1 and S3) are compared in Figure $7 \mathrm{~b}$, again including the Cathlapotle salmon. The mean $\delta^{15} \mathrm{~N} \%$ value for the Namu humans is $19.3 \%$, which is higher than the Namu dog samples by more than $2 \%$. Similar offsets between human and dog values have been observed elsewhere (e.g. Tankersley and Koster 2009, Rick et al. 2011). Nitrogen values for the Namu and Cathlapotle dogs are very close and both are higher than the Cathlapotle salmon values, indicating both sets of dogs were eating salmon to some degree. The nitrogen 
values of the Keatley Creek dogs fall much closer to the terrestrial prey and thus again, suggest a greater proportion of terrestrial food sources were consumed at this interior location than at Cathlapotle. Nitrogen values for Interior humans cover an extreme range from essentially terrestrial herbivore to top ranked carnivore. At minimum, as with

591 the Interior human $\delta{ }^{13} \mathrm{C} \%$ values, these point to a varied interior diet.

6. Discussion

\section{1 aDNA}

596 The primary goal of the ancient DNA analysis was to confirm the osteological 597 identification of the skeletal elements as domestic dog. It did so. DNA species 598 identification of archaeological remains is no longer new; this study reinforces the 599 usefulness of DNA species identification of faunal remains for subsequent isotopic 600 analyses (e.g. Byrd et al. 2013).

601 The analysis also pinpoints the presence of two ancient North American 602 haplotypes within the LCR. Both haplotypes are relatively well dispersed in North 603 America, and, for haplotype A3, may represent one of the earliest matrilineal types to 604 enter the Americas, as evidenced by its presence at the Koster site in Illinois (Thalmann 605 et al. 2013). The relatively large geographic distribution of both haplotypes points to the 606 challenges in using mtDNA alone to effectively separate regional dog populations since 607 dogs may have been regularly exchanged among human groups. Although, based on 608 the limited ancient mtDNA data that has been generated to date (Figure 6), there 
609 appears to be little overlap between haplotypes identified in pre-contact Arctic sites

610 (Brown et al. 2013) with those on the Northwest Coast and further south into Central

611 and South America (Figure 6). With further data, it will be intriguing to investigate to

612 what extent these phylogeographic patterns reflect human migration and interaction

613 patterns in the New World. The genetic structure of regional dog populations has the

614 potential to yield valuable data on the regional and local structure of human behavior,

615 however, this type of analysis will require systematically collected samples targeting the

616 same genetic locus in order to produce comparable-population level data. The wide

617 geographic and temporal distribution of both Cathlapotle haplotypes also suggests

618 neither is a candidate to represent the wool dog.

619

$620 \quad 6.2 \quad$ Isotopic analysis

621 The dog isotope values are an average of all of the protein that was consumed by the

622 dogs while the bones were formed and remodeled over their lifetimes, so provide a

623 general view of the protein sources of diet over many years. As isotope analysis is a

624 general measure of diet, it cannot determine occasional consumption of other foods like

625 seals or salmon, but instead indicates the main dietary protein sources, and in this case

626 the isotope results show the dogs' protein intake was largely from marine sources,

627 conforming closely to other isotopic analyses of archaeological dogs from Cascadia

628 (e.g. Barta, 2006; Grier, 2006; Cannon et al., 1999). At Cathlapotle the fish are most

629 likely eulachon primarily based on the low nitrogen isotope values. 
The apparently narrow diet for dogs contrasts sharply with the ethnohistorical

631 and zooarchaeological records, which together strongly indicate a great diversity of

632 animals was part of human subsistence, more like the diet in the British Columbia

633 interior than on the coast. Dogs had available to them a rich and diverse array of

634 resources harvested in terrestrial and freshwater habitats but they were not foraging

635 across the full spectrum of animals being brought into Cathlapotle. Taking three

636 examples, the people at Cathlapotle took wapiti in large numbers. The wapiti at

637 Cathlapotle were much larger than modern wapiti in North America (Lyman 2006). The

638 Roosevelt elk is the largest modern wapiti. Bulls weigh $300-500 \mathrm{~kg}$ and cows $260-285$

$639 \mathrm{~kg}$. Many of the Cathlapotle wapiti would have been even larger based on skeletal

640 evidence. The animals were hunted at Cathlapotle for their hides, meat and tool bone.

641 The processed hides were certainly traded (Gibson 1992) and virtually all bone tools

642 were made from wapiti metapodials (Fuld 2011). While the meat was eaten by humans,

643 it was not being fed to the dogs to any degree. For example, only a very small number

644 of wapiti bones (100 of an NISP of 3224) (Lyman 2003) show carnivore gnawing.

645 Several freshwater fish taxa were taken, especially minnows and suckers, in large

646 numbers that would have been available to scavenging dogs. Again, the dogs were not

647 eating these fish. Finally, the dogs were not eating the harvested water birds present in

648 the site. We conclude from this that the dogs were not simply eating what they

649 encountered from the human diet (i.e. Rick et al., 2011), nor were they provisioning

650 themselves in the local environment assuming their feeding habits were similar to

651 coyotes', which primarily eat small mammals but take animals as large as deer and as 
652 small as insects as well as seasonal fruit (Maser et al.1984). Presumably coyotes'

653 isotopic values would fall within the terrestrial cluster in Figure 5 (e.g. Warsen et al.

654 2014). Rather, the dogs appear to have been fed anadromous fish, which we think were

655 mainly eulachon, with some salmon and sturgeon. They also may have been fed

656 lamprey for which we have no isotopic data.

657 This conclusion raises questions about the management of dogs in the LCR and 658 perhaps elsewhere on the Northwest Coast. Controlling their diet implies the dogs were 659 tied or penned and that there was selectivity in their feeding. Penning or tying would be 660 necessary to keep dogs from scavenging for scraps. Currently the wool dog is the only 661 evidence for dog management on the Northwest Coast. The development of a

662 functionally specific dog breed requires long-term controlled breeding (Schulting 1994).

663 Of course, this is not evidence for controlled feeding, but indicates it is not outside the 664 realm of possibility. We have already been told LCR dogs were not allowed salmon 665 hearts or boney salmon fillets but that the dogs had ready access to other salmon 666 scraps. The early documentary record is mute as to whether dogs were tied or 667 restrained in any way (e.g. Mack i.p.) although Mack quotes one journal passage which 668 implies the presence of dog packs. These apparent contradictions are not resovable 669 with the data at hand. The questions also include why preferential feeding? PSD is one 670 possibility. However, this potentially is carried by most anadromous and some 671 freshwater fish, many of which the dogs were eating. Additionally, if that was the 672 problem, why not feed the dogs the available cervid meat. They were feeding the dogs 673 eulachon, which may not have carried SPD. If that can be demonstrated to be the case, 
674 SPD could explain the eulachon preference. The occupants of Cathlapotle may not

675 have been alone in feeding their dogs small, abundant marine fish. Grier has argued

676 that the marine isotopic dietary signals from dog bones at the Dionisio Point site in the

677 Salish Sea of southern British Columbia resulted from a diet heavy in herring (Clupea sp.), another small fish taken in vast numbers (Grier 2006). Since they do not enter fresh water, herring are at no risk of SPD infection. If the dogs were immune to SPD, the preferential feeding may rather be the result of the same kinds of cultural rules that prohibited dogs' access to salmon fillets and hearts. zooarchaeological record pose the issue whether the dogs' diet is a close proxy for the diet of Cathlapotle's human occupants who harvested the diverse array of food resources. We suggest the answer is no, it is not, for the reasons developed above. The alternative hypotheses is that the town's occupants did not eat the deer or elk meat they brought in or any of the freshwater fish they harvested in large amounts. We think that unlikely. There are other documented cases were the diets of coresident dogs and humans differed (e.g. Bocherens et al. 2013, Tsutaya et al. 2014). It is for these reasons that we do not see our results as a test of Butler's original hypothesis (Butler 2000). Our results do not undermine the potential to use dogs as proxies for human

692 diets. Rather our study highlights the importance of using additional data such as 693 documentary and zooarchaeological records, and other lines of evidence, (e.g. Guiry 694 2012) to evaluate the linkage. It also reinforces that isotopic analyses on a range of 
695 potential prey items and background species in a site is an essential part of establishing

696 the use of dog isotopes as a proxy for human diet. .

697

698 7. Conclusions

699

700 Our results are consilient with other stable isotope analyses of archaeological dog

701 bones on the Northwest Coast: the dogs were eating a diet dominated by marine fish.

702 However, these results are not consilient with other lines of evidence about human diet

703 at Cathlapotle and in the LCR which suggest a more diverse diet in which marine fish

704 were but one keystone resource, and included numerous terrestrial and freshwater

705 resources. The dogs were not foraging across the human diet nor self-provisioning in

706 the local environment. This points to the strong likelihood the dogs at Cathlapotle were

707 being preferentially fed the marine fish, most likely eulachon (and possibly lamprey) with

708 perhaps the addition of salmon and occasional sturgeon. These results reinforce the

709 need for background isotopic values for a range of animals present in the

710 zooarchaeological collection from a site.

711 Our study points to the need for better understanding PSD in order to evaluate its

712 effects, if any, on dog diets in the region of North America in which it is endemic. The

713 issue is moot if dogs in the region were immune. If they were not, then it likely shaped

714 what they were fed which has obvious implications for stable isotope studies in the

715 affected region. One particularly pressing issue is determining which fish carried it and

716 which did not. 
The aDNA analysis confirmed the osteological identification of the skeletal

718 elements as dog, thus eliminating a potential source of error. We suggest aDNA analysis should also be used to confirm ambiguous identifications increasing the number of specimens available for isotopic analysis. We also believe that in the long run, the population structures of ancient dogs provide a very promising line of evidence about large scale human interactions, and requires a large-scale analysis of pre-contact canid remains to address the issue.

Acknowledgements

The analyses were supported by National Endowment for the Humanities Grant RZ50601-06 and funding provided by Jean and Ray Auel. The excavations at Cathlapotle were supported by the US Fish and Wildlife Service, Portland State University, The

730 Friends of the Wapato Valley and Jean and Ray Auel. We thank Tony Johnson for sharing his knowledge about Chinook dogs and related practices. We thank Robert Boyd for directing our attention to Salmon Poisoning Disease and Cheryl Mack for giving prepublication access to her paper on LCR dogs in the early contact period. We wish to thank the USFWS staff, especially Anan Raymond, who ultimately made the project possible and everyone for their financial support. We also thank the Chinook Indian Nation for their long and unflagging support for the Cathlapotle Project, as well as that of the Confederated Tribes of the Grand Ronde. The paper was materially 
738 improved by the comments of five anonymous reviewers. Any errors of course are ours.

740 References

741 Ambrose, S., 1990. Preparation and characterization of bone and tooth collagen for

742 stable carbon and nitrogen isotope analysis. J. Archaeol. Sci. 17, 431-451.

743

744 Ames, K. M., Maschner, H.D.G., 1999. Peoples of the Northwest Coast: their

745 archaeology and prehistory. Thames and Hudson Ltd. London.

746

747 Ames, K.M., Sobel, E.A., 2009. Finding and dating Cathlapotle. Archaeology in

748 Washington 15, 9-32.

749

750 Ames, K.M., Smith, C.M., Bourdeau A., 2008. Large domestic pits on the Northwest

751 Coast of North America. J. Field Archaeol. 33, 3-18.

752

753 Ames, K.M., Smith, C.M., Cornett, W.L., Sobel, E.A., Hamilton S.C., Wolf, J., Raetz, D.,

754 1999. Archaeological investigations at 45CL1 Cathlapotle (1991-1996): Ridgefield

755 National Wildlife Refuge, Clark County, Washington; a preliminary report. U.S.

756 Department of Interior, Fish and Wildlife Service, Region 1, Portland.

757

758 Bandelt, H.-J., Forster, P., Roehl, A., 1999. Median-joining networks for inferring

759 intraspecific phylogenies. Mol. Biol. Evol. 1637- 1648. 
760

761

762

763

764

765

766

767

768

769

770

771

772

773

774

775

776

777

778

779

780

781

Barta, J. L., 2006. Addressing Issues of domestication and cultural continuity on the Northwest Coast using ancient DNA and dogs. PhD Thesis. McMaster University.

Bocherens, H., Drucker, D., 2003. Trophic level isotopic enrichment of carbon and nitrogen in bone collagen: case studies from recent and ancient terrestrial ecosystems, Int. J. Osteoarchaeology 13, 46 - 53.

Bocherens, H., Drucker, D.G., Germonpré, M., Lázničková-Galetova, M., Naito, Y.I., Wissing, C., Brůžek, J., Oliva, M., 2014. Reconstruction of the Gravettian food-web at Předmostí I using multi-isotopic tracking (13C, 15N, 34S) of bone collagen. Quatern. Int. In Press, Corrected Proof, Available online 23 November 2014.

Boyd, R. T., 1999. The coming of the spirit of pestilence: introduced infectious diseases and population decline among Northwest Coast Indians, 1774 - 1874. University of Washington Press, Seattle.

Boyd, R. T., 2013. Lower Chinookan Disease and Demography. In Boyd R.T., Ames K.M., Johnson T. (Eds), Chinookan Peoples of the Lower Columbia River. University of Washington Press, Seattle, pp. 229 - 249.

Boyd, R.T., Hajda, Y., 1987. Seasonal population movement along the Lower Columbia River: The social and ecological context. Am. Ethnol. 14, 309-326. 
782 Boyko R.H., Boyko, A., 2014. Conservation and the population genetic structure of

783 dogs. Free-ranging dogs and Wildlife Conservation, M. E. Gompper. Oxford University

784 Press, Oxford, pp. $-185-210$.

785

786 Brotherton, P., Endicott, P., Sanchez, J.J., Beaumont, M., Barnett, R., Austin, J.,

787 Cooper, A., 2007. Novel high-resolution characterization of ancient DNA reveals C $>$ U-

788 type base modification events as the sole cause of post mortem miscoding lesions.

789 Nucleic Acids Res. 35(17), 5717-5728. doi: 10.1093/nar/gkm588.

790

791 Brown, S.K., Darwent, C.M., Sacks, B.N., 2013. Ancient DNA evidence for genetic

792 continuity in arctic dogs. J. Archaeol. Sci.40, 1279-1288.

793

794 Brown, T.A., Nelson, D.E., Vogel, J.S., Southon, J.R., 1988. Improved collagen

795 extraction by modified Longin method. Radiocarbon 30, 171-177.

796

797 Butler, V. L., 2000. Resource depression on the Northwest Coast of North America.

798 Antiquity 74, 649-661.

799

800 Butler, V. L., 2002. Fish remains from Cathlapotle: preliminary report. Portland State

801 University, Portland.

802 
803 Butler, V.L., Campbell, S.K., 2004. Resource intensification and resource depression in

804 the Pacific Northwest of North America: A zooarchaeological review. J. World Prehist.

$805 \quad 18,327-405$.

806

807 Butler, V.L., Martin, M.A., 2013. Aboriginal fisheries of the Lower Columbia River. In

808 Boyd, R.T, Ames, K.M., Johnson, T. (Eds.), Chinookan Peoples of the Lower Columbia

809 River. University of Washington Press, Seattle, pp. $80-105$.

810

811 Byrd, B., Cornellas, A., Eerkens, J.W., Rosenthal, J.S., Carpenter, T.R., Leventhal, A.,

812 Leonard, J.A., 2013. The role of canids in ritual and domestic contexts: new ancient

813 DNA insights from complex hunter-gatherer sites in prehistoric Central California. J.

814 Archaeol. Sci 40, $2176-2189$.

815

816 Campbell, S.K., 1991. A critical review of protohistoric research in the Columbia

817 Plateau. Archaeology in Washington 3, 41-66.

818

819 Campbell, S.K., Butler, V.L., 2010. Fishes and Loaves? Explaining Sustainable, Long-

820 Term Animal Harvesting on the Northwest Coast Using the "Plant Paradigm". In Dean,

821 R.M. (Ed.), The Archaeology of Anthropogenic Environments. Center for Archaeological

822 Investigations, Occasional Paper No. 37, Carbondale, pp. 175-202. 
824 Cannon, A., 1991. The economic prehistory of Namu, Archaeology Press, Simon Fraser

825 University, Burnaby, British Columbia.

826

827 Cannon, A., Schwarcz, H.P., Knyf, M. 1999. Marine-based subsistence trends and the 828 stable isotope analysis of dog bones from Namu, British Columbia. J. Archaeol. Sci. 26, $829 \quad 399-407$.

830

831 Chisholm, B.S., Nelson, D.E., and Schwarcz, H.P. 1983. Marine and terrestrial protein

832 in prehistoric diets on the British Columbia Coast. Curr. Anthropol. 24, 396-398.

834 Corr, L.T., Richards, M.P., Grier, C., Mackie, A., Beattie, O., Evershed, R.P., 2009.

835 Probing dietary change of the Kwa"da y Da"n Ts'ı’nchi cindividual, an ancient

836 glacier body from British Columbia: II. Deconvoluting whole skin and bone

837 collagen d13C values via carbon isotope analysis of individual amino acids. J. Archaeol.

838 Sci. $36,12-18$

839

840 Coupland, G., Stewart, K., Patton, K., 2010. Do you never get tired of salmon?

841 Evidence for extreme salmon specialization at Prince Rupert harbour, British Columbia.

842 J. Anthropol. Archaeol. 29, 189-207.

843

844 Crockford S. 1997. Osteometry of Makah and Coast Salish Dogs. Archaeology Press,

845 Simon Fraser University, Burnaby, British Columbia.

846 
847 Crockford, S., Pye, C.J., 1997. Forensic Reconstruction of Prehistoric Dogs from the

848 Northwest Coast. Can. J. Archaeol. 21, 149-153.

849

850 Cromwell, R.J., 2011. A Typological analysis of the historic ceramic ware sherds

851 recovered from the Cathlapootle (45CL1) site and the Meier (35CO5) site. Fort

852 Vancouver National Historic Park, Vancouver, WA..

853

854 DeNiro, M.J., 1986. Post-mortem preservation and alteration of in vivo bone collagen

855 isotope ratios in relation to paleodietary reconstruction. Nature $37,806-809$.

856

857 Deur, D.E., Turner, N.J. (Eds.), 2005. Keeping It Living: Traditions of Plant Use and

858 Cultivation on the Northwest Coast of North America. University of Washington Press,

859 Seattle.

860

861 Eriksson, G., Zagorska, I. 2003. Do dogs eat like humans?: Marine stable isotope

862 signals in dog teeth from inland Zvejnieki. In Larssen, L. (Ed.), Mesolithic on the Move.

863 Oxbow Books, Oxford, pp, 160-168.

864

865 Fischer, A., Olsen, J., Richards, M.P., Heinemeier, J., Sveinbjörnsdóttird, A.E., Bennike,

866 P., 2007. Coast-inland mobility and diet in the Danish Mesolithic and Early Neolithic: 
867 evidence from stable isotope values of humans and dogs. J. Archaeol. Sci. 34,2125-

8682150.

869

870 Frederick, G., 2009. Report on the Meier (35CO5) and Cathlapotle (45CL1)

871 archaeological bird remains. Pacific Identifications, Inc., Victoria.

872

873 Fuld, K.A., 2011. The technological role of bone and antler artifacts on the Lower

874 Columbia: a comparison of two contact period Sites. MA Thesis, Portland State

875 University, Portland.

876

877

878 Gibson, J.R., 1992. Otter skins, Boston ships and China goods: the maritime fur trade of

879 the Northwest Coast, 1785 - 1841. University of Washington Press, Seattle.

880

881 Gilbert, M.T.P., Binladen, J., Miller, W., Wiuf, C., Willerslev, E., Poinar, H., Carlson, J.E.,

882 Leebens-Mack, J.H., and Schuster, S.C. 2007. Recharacterization of ancient DNA

883 miscoding lesions: insights in the era of sequencing-by-synthesis. Nucleic Acids Res.

884 35, 1-10. doi: 10.1093/nar/gkl483.

885

886 Grier, C., 2006. Affluence on the prehistoric Northwest Coast of North America. In Grier,

887 C., Kim, J., Uchiyama, J. (Eds.) Beyond affluent foragers: rethinking hunter-gatherer

888 complexity. Oxbow Books, Oxford, pp. 126-135. 
890 Groesbeck A.S, Rowell, K., Lepofsky, D., Salomon, A.K. 2014. Ancient Clam Gardens

891 Increased Shellfish Production: Adaptive Strategies from the Past Can

892 Inform Food Security Today. PLoS ONE 9(3), e91235.

893 doi:10.1371/journal.pone.0091235

894

895 Guiry, E.J., 2012. Dogs as Analogs in Stable Isotope-Based Human Paleodietary 896 Reconstructions: A Review and Considerations for Future Use. J. Archaeol.

897 Method Theory 19,351-376

898

899 Guiry, E.J., 2013. A canine surrogacy approach to human paleodietary bone chemistry:

900 past development and future directions. Archaeol. Anthropol. Sci. 5,275-286

901

902 Hajda, Y., 1984. Regional social organization in the Greater Lower Columbia, 1792-

903 1830. PhD Thesis. University of Washington.

904

905 Hall, T.A., 1999. BioEdit: a user-friendly biological sequence alignment editor and

906 analysis program for Windows 95/98/NT. Nucl. Acids. Symp. Ser. 4195-98.

907

908 Hayden, B., 1997. The Pithouses of Keatley Creek. Harcourt Brace College Publishers, 909 Fort Worth. 
911 Headley, S.A., Scorpio, D.G., Vittodoto, O., Dumler, J.S., 2011. Neorickettsia

912 helminthoeca and salmon poisoning disease: A review. Vet. J. 187,165-173.

913

914 Igler, D., 2004. Diseased goods: global exchanges in the eastern Pacific Basin, 1770-

915 1850. Am. Hist. Rev. 109, 693-719.

916

917 Ishiguro, N., Okumura, N., Matsui, N.A., Shigehara, N., 2000. Molecular genetic

918 analysis of ancient Japanese dogs. In Crockford, S.J. (Ed.), Dogs through time, an

919 archaeological perspective: proceedings of the 1st ICAZ symposium on the history of

920 the domestic dog, Archaeopress, Oxford, pp. 287-292.

921

922 Kaehler, G.A., 2002. Patterns in glass: The interpretation of European glass trade

923 beads from two protohistoric sites in the Greater Lower Columbia River Region. MA

924 Thesis, Portland State University, Portland.

925

926 Kim, K.S., Lee, S.E., Jeong, H.W., Ha, J.H., 1998. The complete nucleotide sequence

927 of the domestic dog (Canis familiaris) mitochondrial genome. Mol. Phylogenet. Evol. 10, $928 \quad 210-220$.

929

930 Kumar, S., Tamura, K., Nei, M., 2004. MEGA3: Integrated software for Molecular

931 Evolutionary Genetics Analysis and sequence alignment. Brief Bioinform 5, 150-163. 
933 Leonard, J.A., Wayne, R.K., Wheeler, J., Valadez, R., Guillen,S., Vilá, C., 2002. Ancient

934 DNA evidence for Old World origin of New World dogs. Science 298, 1613-1616.

936 Lyman, R.L., 2003. Mammalian zooarchaeology of Cathlapotle (45CL1): descriptive

937 paleontology and taphonomic analysis. Report of File, Portland State University,

938 Portland.

939

940 Lyman, R.L., 2006. Archaeological evidence of anthropogenically induced twentieth-

941 century diminution of North American wapiti, Am. Midl. Nat. 156, 88-98.

942

943 Lyman, R.L., Harpole, J.L., Darwent, C., Church, R,. 2002. Prehistoric Occurrence of

944 Pinnipeds in the Lower Columbia River. Northwestern Naturalist 83:1-6.

945

946

947

948

949

950 Maser, C., Mate, B.R., Franklin, J.F., Dyrness, C.T., 1984. Natural History of Oregon

951 Coast Mammals. University of Oregon Museum of Natural History, Eugene.

952

953 954 Press, Orlando.

955

Mack, C., i.p. Big Dog/Little Horse - Ethnohistorical and linguistic evidence for the changing role of dogs on the Mid-and-Lower Columbia in the Nineteenth Century. Journal of Northwest Anthropology 49.

Matson, R. G.,Coupland, G. 1995. The prehistory of the Northwest Coast. Academic 
956 McKechnie, I., Lepofsky, D., Moss, M.L., Butler, V.L., Orchard, T.J., Coupland, C.,

957 Foster, C., Caldwell, M., Lertzman, K., 2014. Archaeological data provide alternative

958 hypotheses on Pacific herring (Clupea pallasii) distribution, abundance, and variability

959 Proc Natl Acad Sci 2014111 (9) E807-E816; published on line February 18, 2014,

960 doi:10.1073/pnas.1316072111

961

962 Miller, J. 2012. Lamprey "Eels" in the Greater Northwest: A Survey of Tribal Sources,

963 Experiences, and Sciences. Journal of Northwest Anthropology 46, 65-84.

964

965 Minagawa, M., Wada, E.,1984. Stepwise enrichment of $15 \mathrm{~N}$ along food chains: Further

966 evidence and the relation between $\delta 15 \mathrm{~N}$ and animal age, Geochimica et Cosmochimica

967 Acta 48, $1135-1140$.

968

969 Misarti, N. (2007). Six thousand years of change in the Northeast Pacific: an

970 interdisciplinary view of maritime ecosystems., PhD Thesis, University of Alaska.

971

972 Monks, G.G., 1987. Prey as Bait: The Deep Bay Example. Can. J. Archaeol. 11, 119-

973142.

974

975 Moss M.L., Cannon, A. (Eds.), 2011. The Archaeology of North Pacific Fisheries.

976 University of Alaska Press, Fairbanks.

977 
978 Moulton, G.E., (Ed.), 1990. The journals of Lewis and Clark. University of Nebraska

979 Press, Lincoln.

980

981 Pereira L., Van Asch, B., Amorima, A., 2004. Standardisation of nomenclature for dog

982 mtDNA D-loop: a prerequisite for launching a Canis familiaris database Forensic Sci.

983 Int. 141, $99-108$

984

985

986 Post, D.M., 2002. Using stable isotopes to estimate trophic postions: models, methods

987 and assumptions. Ecology 83, $703-718$.

988

989 Richards, M.P., Hedges, R.E.M., 1999. Stable isotope evidence for similarities in the

990 types of marine foods used by Late Mesolithic humans at sites along the Atlantic coast

991 of Europe. J. Archaeol. Sci. 26, 717-722.

992

993 Rick, T.C., Culleton, B.J., Smith, C.B., Johnson, J.R., Kennett, D.J., 2011. Stable

994 isotope analysis of dog, fox, and human diets at a Late Holocene Chumash village (CA-

995 SRI-2) on Santa Rosa Island, California. J. Archaeol. Sci. 38, 1385 - 1393.

996

997 Rollins, P.A., (Ed.), 1935 The Discovery of the Oregon Trail: Robert Stuart's Narratives

998 of his Overland Trip Eastward from Astoria in 1812-13. University of Nebraska Press,

999 Lincoln.

1000 
1001 Romanuk, T.N., Levings, C.D., 2005. Stable isotope analysis of trophic position and 1002 terrestrial vs. marine carbon sources for juvenile Pacific salmonids in nearshore marine 1003 habitats. Fisheries Manag. Ecol.12, 113 - 121.

1004

1005 Savolainen, P., Zhang, Y.P.,, Luo, J., Lundeberg, J., Leitned, J., 2002. Genetic 1006 evidence for an East Asian origin of domestic dogs. Science 298, 1610-1611.

1007

1008 Schoeninger, M.J., DeNiro, M.J., 1984. Nitrogen and carbon isotopic composition of 1009 bone collagen from marine and terrestrial animals. Geochim. Cosmochim. Ac. 48, $625-$ 1010339.

1011

1012 Schulting R., 1994. The Hair of the Dog: The Identification of a Coast Salish Dog-Hair 1013 Blanket from Yale, British Columbia. Can. J. Archaeol. 18, 57 - 76.

1014

1015 Schwarcz, H.P., Chisholm, B.S., Burchell, M., 2014. Isotopic Studies of the Diet of the

1016 People of the Coast of British Columbia. Am. J. Phys. Anthropol. 155, 460-468

1017

1018 Shepard, E., 2014. Building and Maintaining Plankhouses at Two Villages on the

1019 Southern Northwest Coast of North America MA Thesis, Portland State University, 1020 Portland. 
1022 Smith, C.M., 2008. The Organization of production among sedentary foragers of the

1023 Southern Pacific Northwest Coast. Archaeopress, Oxford.

1024

1025 Sobel, E.A., 2004. Social complexity and corporate households on the Southern

1026 Northwest Coast of Norh America, A.D. 1450-1855. PhD Thesis, University of Michigan.

1027

1028 Solazzo, C., Heald, S., Ballard, M.W., Ashford, D.A., DePriest, P.T., Koestler, R.J.,

1029 Collins, M.J. 2011. Proteomics and Coast Salish blankets: A Tale of Shaggy Dogs?

1030 Antiquity 85, 1418-1432.

1031

1032 Speller, C.F., Kooyman, B., Rodrigues, A.T., Langemann, E.G., Jobin, R.M., Yang,

1033 D.Y., 2014. Assessing prehistoric genetic structure and diversity of North American elk

1034 (Cervus elaphus) populations in Alberta, Canada. Can J. Zool. 92, 285-298.

1035

1036 Szpak, P., Orchard, T.J., Gröck, D.R., 2009. A Late Holocene vertebrate food web from 1037 southern Haida Gwaii (Queen Charlotte Islands, British Columbia). J. Archaeol. Sci. 36, $1038 \quad 2734-2741$.

1039

1040 Tankersley, K.B., Koster, J.M., 2009. Sources of Stable Isotope Variation in

1041 Archaeological Dog Remains. N. Am. Archaeol. 30, 361-375.

1042 
1043 Thalmann, O., Shapiro, B., Cui, P., Schuenemann, V.J., Sawyer, S.K., Greenfield, D.L.,

1044 Germonpré, M.B., Sablin, M.V., López-Giráldez, F., Domingo-Roura, X., Napierala, H.,

1045 Uerpmann, H.-P., Loponte, D.M., Acosta, A.A., Giemsch, L., Schmitz, R.W.,

1046 Worthington, B., Buikstra, J.E., Druzhkova, A., Graphodatsky, A.S., Ovodov, N.D.,

1047 Wahlberg, N., Freedman, A.H., Schweizer, R.M., Koepfli, K.-P., Leonard, J.A., Meyer,

1048 M., Krause, J., Pääbo, S., Green, R.E., Wayne, R.K., 2013.. Complete Mitochondrial

1049 Genomes of Ancient Canids Suggest a European Origin of Domestic Dogs. Science

$1050 \quad 342(6160), 871-874$.

1051

1052 Thompson, J.D., Higgins, D.G., Gibson, T.J., 1994. CLUSTAL W: improving the

1053 sensitivity of progressive multiples sequence alignments through sequence weighting,

1054 position-specific gap penalties and weight matrix choice. Nucleic Acids Res. 22, 4673-

10554680.

1056

1057 Tsutaya, T., Naito, Y., Ishida, H., Yonedai, M., 2014. Carbon and nitrogen isotope

1058 analyses of human and dog diet in the Okhotsk culture: perspectives from the Moyoro

1059 site, Japan. Anthropol. Sci. 122 (2), 89-99.

1060

1061 Turner, N.J., 2014. Ancient Pathways, Ancestral Knowledge: Ethnobotany and

1062 Ecological Wisdom of Indigenous Peoples of Northwestern North America. McGill-

1063 Queen's University Press, Montreal. 
1064 Vancouver, G., 1926. The Exploration of the Columbia River by Lieutenant W.R.

1065 Broughton, October 1792: An Extract of the Journal of Captain George Vancouver,

1066 Press of the Longview Daily News, Longview, WA.

1067

1068 Vilà, C., Savolainen, P., Maldonado, J.E., Amorim, I.R., Rice, J.E., Honeycutt, R.L.,

1069 Crandall, K.A., Lundeberg, J., Wayne, R.K., 1997. Multiple and ancient origins of the

1070 domestic dog. Science 276,1687-1689.

1071

1072 Warsen, S.A., Frair, J.L., Teece, M.A., 2014. Isotopic investigation of niche partitioning

1073 among native carnivores and the non-native coyote (Canis latrans). Isot. Environ.

1074 Health Stud.50, 414-424

1075

1076 Yang, D.Y., Eng, B., Waye,J.S., Dudar, J.C., Saunders, S.R., 1998. Improved DNA

1077 extraction from ancient bones using silica-based spin columns. Am. J. Phys. Anthropol.

$1078 \quad 105,539-543$.

1079

1080 Yang, D.Y., Speller, C.F., 2006Co-amplification of cytochrome b and D-loop mtDNA

1081 fragments for the identification of degraded DNA samples. . Mol. Ecol. Notes 6(3), 605-

1082608.

1083

1084

1085 
1086

Ames et al. List of Tables

1087

1088 Table 1 Cathlapotle canid samples, PCR amplification, species identification and

1089 haplotype results.

1090 Table 2 Stable isotope values for archaeological remains of dog and common fauna

1091 from Cathlapotle

1092

1093

1094

1095

1096

1097

1098

1099 
1100

1101

1102

1103

1104

1105

1106

Ames et al. List of Figures

Figure 1 Map of Western North America, showing sites mentioned in the text and the distribution of Cathlapotle Haplotypes as well as other dog haplotypes identified by Barta (2006).

Figure 2. Location of Cathlapotle (45CL1) and the Wapato Valley on the Lower Columbia River in western North America.

Figure 3.Map of Cathlapotle showing positions of the houses, locations of excavation units and units from which the canid elements used here were selected. Map by Emily Shepard.

Figure 4. Pie charts showing percent NISP of different taxa among a) mammals, b) birds and c) and d) fish recovered at Cathlapotle. Mammalian NISP is total NISP recovered in 1/4" screens from all 50 excavation units $\left(240 \mathrm{~m}^{3}\right)$ (Lyman 2003). Taxa represented here have NISP $>100$. The "Other" category includes all taxa with NISP $<100$. The avian fauna is the analyzed sample recovered in $1 / 4$ " screens from 21 excavation units $\left(114 \mathrm{~m}^{3}\right)$ (Frederick 2009). The fish fauna is the analyzed sample from $1210 \mathrm{Itr}$ bulk samples from 12 excavation units (Butler 2002): c) is $4 \mathrm{~mm} \mathrm{mesh,} \mathrm{d)} \mathrm{is} 2$ $\mathrm{mm}$ mesh. The bulk samples were water screened in the field and sorted in the lab. The pie charts are based on data presented in Tables S1-S3, Supplemental Materials. 
1123 Figure 5 Phylogenetic tree displaying the relationships between obtained haplotypes

1124 and some modern Canis haplotypes (Savolainen et al. 2002), with coyote (Canis

1125 latrans) as the outgroup. Accession numbers and haplotypes are listed for Genbank

1126 samples. The numbers at the nodes indicate those bootstrap values above $50 \%$ after

11272000 replications. Squares represent Cathlapotle Haplotype A3 and triangles Haplotype

1128 D25.

1130 Figure 6 Median-joining network comparing Cathlapotle dogs to other ancient domestic

1131 dog haplotypes discovered in the Americas. Each node depicts a separate D-loop

1132 haplotype, and node sizes are proportional to haplotype frequencies in the data set, and

1133 node distances are proportional to the number of mutations between them. Numbers

1134 beside the nodes indicate haplotypes identified on the Northwest Coast (black) and LCR 1135 (white).

1136

1137 Figure 7 Plots of the $\delta^{15} \mathrm{~N}$ and $\delta^{13} \mathrm{C}$ values of the Cathlapotle dogs and other taxa

1138 tested. a) displays the plot of all tested specimen. b) displays the dogs, and taxa with

1139 marine signatures: salmon, sturgeon and eulachon.

1140

1141 Figure 8. Box and whisker graphs comparing the isotopic results for the Cathlapotle

1142 dogs and salmon with Northwest Coast humans (panel a) (see text) and Namu and

1143 Keatley Creek dogs. a) presents $\delta^{13} \mathrm{C}$ values, b) $\delta^{15} \mathrm{~N}$ values. The open circles are the 
1144 data points. The midlines in the diamonds mark the medians, the small internal boxes

1145 the means. The lower hinge is at $25 \%$, the upper hinge at $75 \%$.

1146 
1147 Ames et al. List of Supplemental Materials

1148 Table S1. NISP of mammalian taxa represented at Cathlapotle (Lyman 2002). The

1149 "Other" category in Figure 4 includes the taxa with NISP less than 100. The total NISP

1150 for "Other" is 379.

1151

1152 Table S2. NISP of avian taxa represented at Cathlapotle (Frederick 2009) used in

1153 Figure 4.

1154

1155 Table S3 NISP of Cathlapotle fish taxa recovered in 4 and $2 \mathrm{~mm}$ mesh from 10 I bulk

1156 samples (Butler 2002) used in Figure 4.

1157

1158 
Table 1 Cathlapotle canid samples, PCR amplification, species identification, haplotype and stable isotope results

\begin{tabular}{|c|c|c|c|c|c|c|c|c|c|}
\hline Sample & $\begin{array}{l}\text { aDNA } \\
\text { Code }\end{array}$ & \multicolumn{2}{|c|}{ Element } & Provenience & $\begin{array}{c}\text { Map } \\
\text { Code }^{a}\end{array}$ & Level & $\begin{array}{c}\text { Elevation } \mathrm{m} \\
\text { ASL }\end{array}$ & \multicolumn{2}{|c|}{ Component } \\
\hline 1 & DG1 & \multicolumn{2}{|c|}{ Astragalus } & N106-107/W77-81 & 4 & 4 & 6.35 & \multicolumn{2}{|c|}{ Post contact } \\
\hline 2 & DG2 & \multicolumn{2}{|c|}{ Femur shaft } & N161-163/W104-106 & 1 & 4 & $5.6-5.45$ & \multicolumn{2}{|c|}{ Post contact } \\
\hline 3 & DG3 & \multicolumn{2}{|c|}{ Metacarpal } & N75-77/W76-78 & 5 & 4 & 6.75 & \multicolumn{2}{|c|}{ Post contact } \\
\hline 4 & DG4 & \multicolumn{2}{|c|}{ Mandible \& teeth } & N75-77/W76-78 & 5 & 2 & 6.95 & \multicolumn{2}{|c|}{ Post contact } \\
\hline 5 & DG5 & \multicolumn{2}{|c|}{ Radius \& ulna } & N107-109/W98-100 & 3 & 8 & 5.45 & \multicolumn{2}{|c|}{ Post contact } \\
\hline 6 & DG6 & \multicolumn{2}{|c|}{ Humerus } & N107-109/W98-100 & 3 & 11 & 4.9 & \multicolumn{2}{|c|}{ Pre-contact } \\
\hline 7 & DG7 & \multicolumn{2}{|c|}{ Mandible \& maxilla } & N107-109/W98-100 & 3 & 18 & 3.1 & \multicolumn{2}{|c|}{ Pre-contact } \\
\hline 8 & DG8 & \multicolumn{2}{|c|}{ Premolar (P4) } & N159-160/W103-107 & 2 & 7 & 5.25 & \multicolumn{2}{|c|}{ Post contact } \\
\hline Sample & $\begin{array}{c}\text { PCR } \\
\text { Sequence }^{b}\end{array}$ & $\begin{array}{l}\text { Weight } \\
\text { (g) }\end{array}$ & & Species & p Haplotype & & $\begin{array}{c}\text { Genback } \\
\text { Accession Match }\end{array}$ & $13 \mathrm{C} / 14 \mathrm{C}$ & $15 \mathrm{~N} / 14 \mathrm{~N}$ \\
\hline 1 & 0 & 0.49 & Canis & upus familiaris & mplification & & - & & \\
\hline 2 & 6 & 0.71 & Canis & upus familiaris & A3 & & AF531656 & -14 & 15.2 \\
\hline 3 & 7 & 0.54 & Canis & upus familiaris & A3 & & AF531656 & & \\
\hline 4 & 6 & 0.41 & Canis & upus familiaris & D25 & & AF005295 & -15.1 & 16 \\
\hline 5 & 4 & 1.2 & Canis & upus familiaris & A3 & & AF531656 & -13.7 & 17 \\
\hline 6 & 4 & 0.63 & Canis & upus familiaris & A3 & & AF531656 & -15.1 & 16.5 \\
\hline 7 & 7 & 0.73 & Canis & upus familiaris & A3 & & AF531656 & -14.4 & 17.2 \\
\hline 8 & 4 & 0.41 & Canis & upus familiaris & D25 & & AF005295 & & \\
\hline
\end{tabular}

a .See Figure 3.

b. Indicating how many DNA sequences were obtained from two overlapping DNA fragments. 
Table 2 Stable isotope values for archaeological remains of dog and common fauna from Cathlapotle.

\begin{tabular}{|c|c|c|c|c|c|c|c|c|c|}
\hline $\begin{array}{c}\text { Lab number } \\
\text { (PSU } \\
\text { sample } \\
\text { number }\end{array}$ & Species & Element & Component & $\begin{array}{c}\text { collagen } \\
\%\end{array}$ & $\begin{array}{l}13 \mathrm{C} / \\
14 \mathrm{C}\end{array}$ & $\begin{array}{l}15 \mathrm{~N} / \\
14 \mathrm{~N}\end{array}$ & $\% \mathrm{C}$ & $\% \mathrm{~N}$ & $\mathrm{C}: \mathrm{N}$ \\
\hline \multicolumn{10}{|l|}{ Beta 262006} \\
\hline $\begin{array}{c}\text { (PSU 2) } \\
\text { Beta 262007 }\end{array}$ & Canis lupus familiaris (Dog) & $\begin{array}{l}\text { femur shaft } \\
\text { mandible with } 2\end{array}$ & Postcontact & $N D^{a}$ & -14 & 15.2 & ND & ND & ND \\
\hline (PSU 4) & Canis lupus familiaris (Dog) & teeth & Postcontact & $N D^{a}$ & -15.1 & 16 & ND & ND & ND \\
\hline \multicolumn{10}{|l|}{ Beta 262008} \\
\hline (PSU 5) & Canis lupus familiaris (Dog) & radius and ulna & Postcontact & $N D^{a}$ & -13.7 & 17 & ND & ND & ND \\
\hline \multicolumn{10}{|l|}{ Beta 262009} \\
\hline (PSU 7) & Canis lupus familiaris (Dog) & mandible & Pre-contact & $N D^{a}$ & -14.4 & 17.2 & ND & ND & ND \\
\hline \multicolumn{10}{|l|}{ Beta 262010} \\
\hline (PSU 6) & Canis lupus familiaris (Dog) & humerus & Pre-contact & $N D^{a}$ & -15.1 & 16.5 & ND & ND & ND \\
\hline \multicolumn{10}{|c|}{ Anadromous } \\
\hline Beta 262019 & Acipenser (Sturgeon) & 1 subopercle & & $\mathrm{ND}^{\mathrm{a}}$ & -14.2 & 16.4 & ND & ND & ND \\
\hline Beta 262020 & Acipenser (Sturgeon) & 1 sop & & $N D^{a}$ & -13.4 & 16.4 & ND & ND & ND \\
\hline S-EVA- & Acipenser (Sturgeon) & scute & & 0 & & & & & \\
\hline
\end{tabular}




\begin{tabular}{|c|c|c|c|c|c|c|c|}
\hline S-UBC 1606 & Acipenser (Sturgeon) & scute & 0.31 & -16.6 & 14.9 & 16.6 & 4.4 \\
\hline S-UBC 1607 & Acipenser (Sturgeon) & scute & 0.75 & -17.2 & 15.5 & 35.5 & 9.8 \\
\hline S-UBC 1608 & Acipenser (Sturgeon) & $\begin{array}{l}\text { scute } \\
5 \text { vertebral }\end{array}$ & 0.85 & -21.3 & 14.1 & 11.8 & 1.8 \\
\hline Beta 262017 & Oncorhynchus sp. (Salmon) & $\begin{array}{l}\text { pieces } \\
11 \text { vertebral }\end{array}$ & $N D^{a}$ & -13.8 & 14.7 & ND & ND \\
\hline $\begin{array}{c}\text { Beta } 262018 \\
\text { S-EVA- }\end{array}$ & Oncorhynchus sp. (Salmon) & pieces & $N D^{a}$ & -14 & 14.9 & ND & ND \\
\hline $\begin{array}{l}16210 \\
\text { S-EVA- }\end{array}$ & Oncorhynchus sp. (Salmon) & Vertebrae 2 & 2.5 & -12.4 & 15.4 & 35.8 & 13.1 \\
\hline $\begin{array}{l}16211 \\
\text { S-EVA- }\end{array}$ & Oncorhynchus sp. (Salmon) & Vertebrae 2 & 1.5 & -15.9 & 13.0 & 15.1 & 4.9 \\
\hline $\begin{array}{l}16212 \\
\text { S-EVA- }\end{array}$ & Oncorhynchus sp. (Salmon) & Vertebrae 2 & 1.7 & -13.7 & 14.7 & 30.6 & 11.0 \\
\hline 16213 & Oncorhynchus sp. (Salmon) & Vertebrae 3 & 0.5 & -14.5 & 14.4 & 17.7 & 6.1 \\
\hline S-EVA- & Thaleichthys pacificus & & & & & & \\
\hline 16218 & (Eulachon) & Vertebrae & 0 & & & & \\
\hline S-EVA- & Thaleichthys pacificus & & & & & & \\
\hline 16219 & (Eulachon) & Dentary & 0 & & & & \\
\hline
\end{tabular}




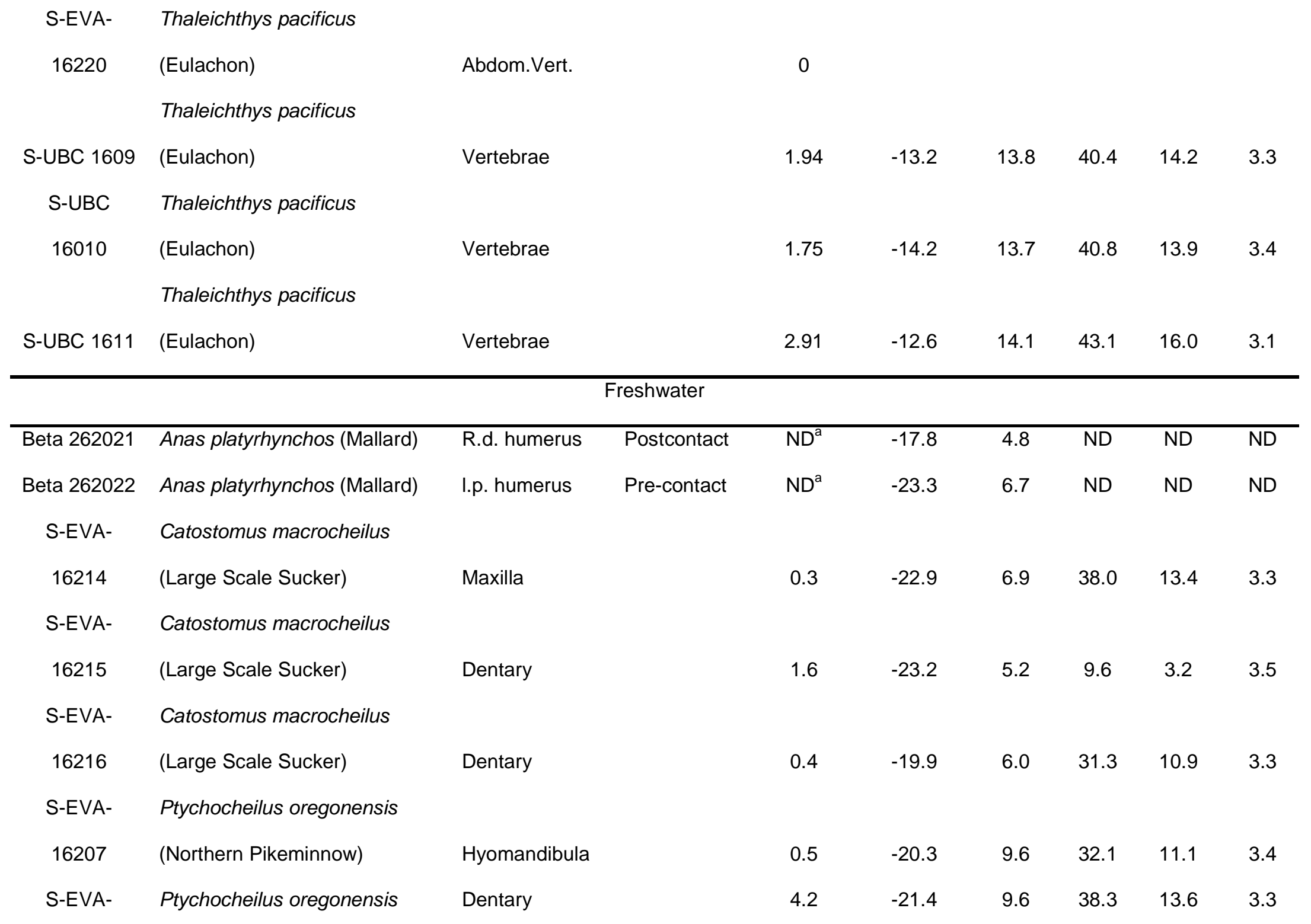




\begin{tabular}{|c|c|c|c|c|c|c|c|c|c|}
\hline 16208 & (Northern Pikeminnow) & & & & & & & & \\
\hline S-EVA- & Ptychocheilus oregonensis & & & & & & & & \\
\hline 16209 & (Northern Pikeminnow) & Quadrate & & 0.3 & -19.5 & 11.1 & 18.4 & 6.0 & 3.6 \\
\hline & & & Terrestrial & & & & & & \\
\hline Beta 262015 & Cervus elaphus (Wapiti) & Calcaneum & Postcontact & ND & -21.8 & 3.8 & ND & ND & ND \\
\hline Beta 262016 & Cervus elaphus (Wapiti) & d. Tibia. Shaft & Pre-contact & ND & -23.2 & 4.2 & ND & ND & ND \\
\hline Beta 262011 & Procyon lotor (Raccoon) & Humerus & Postcontact & ND & -22 & 10.2 & ND & ND & ND \\
\hline Beta 262012 & Procyon lotor (Raccoon) & Mandible & Pre-contact & ND & -21.8 & 8 & ND & ND & ND \\
\hline Beta 262013 & Ursus americanus (Black Bear) & Humerus & Postcontact & ND & -20.1 & 5.8 & ND & ND & ND \\
\hline Beta 262014 & Ursus americanus (Black Bear) & Ischium & Pre-contact & ND & -21.9 & 4.5 & ND & ND & ND \\
\hline
\end{tabular}




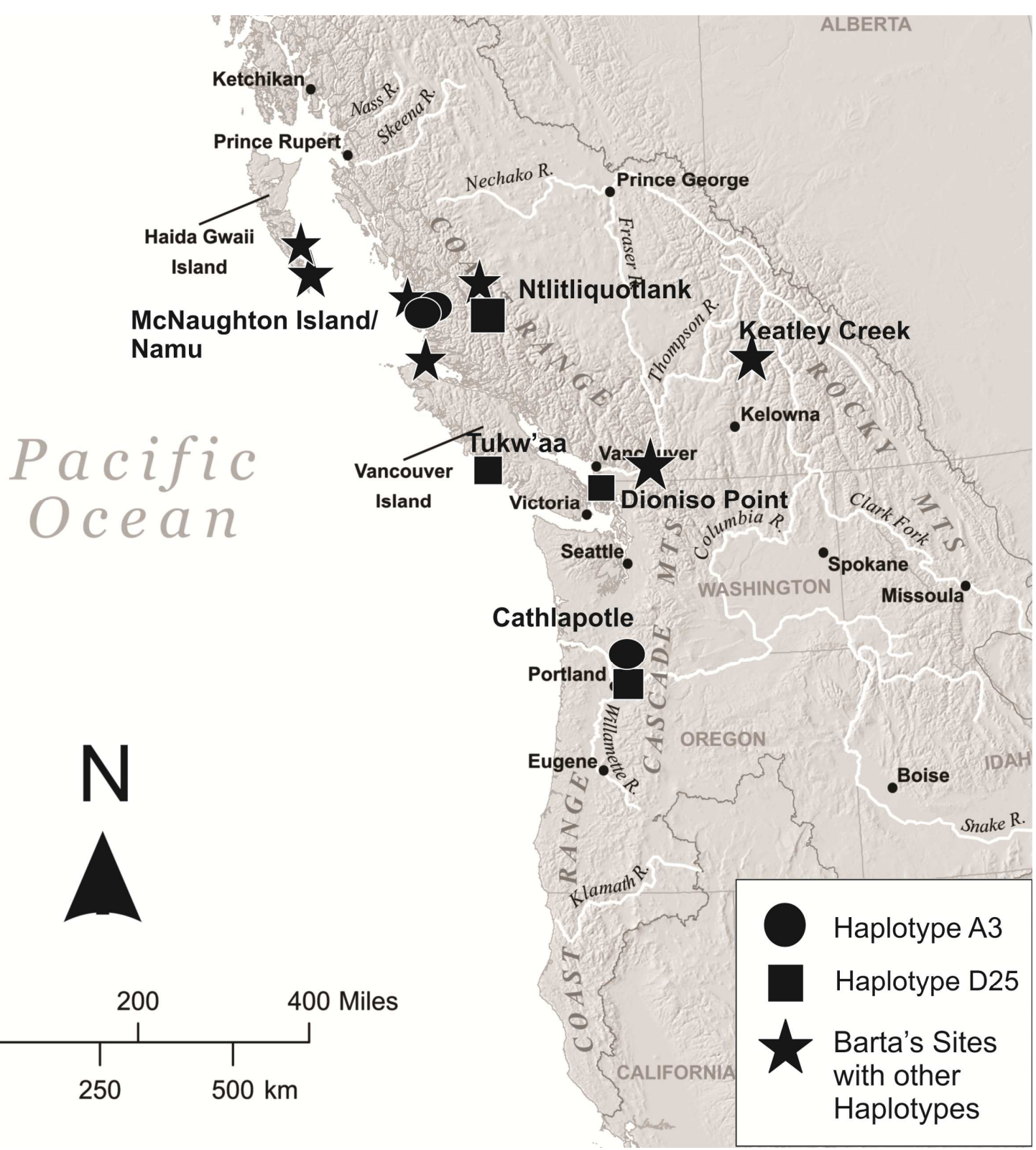




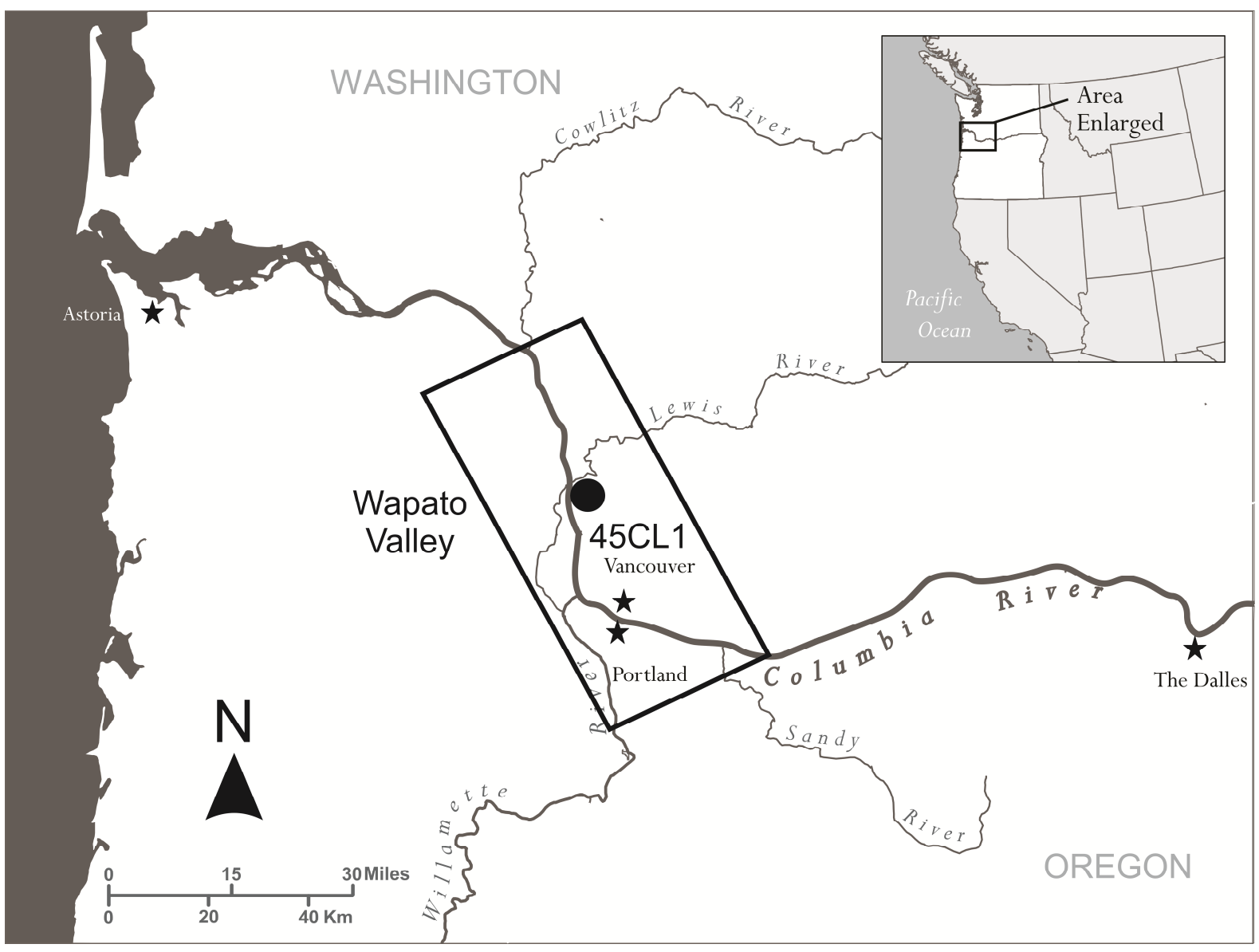




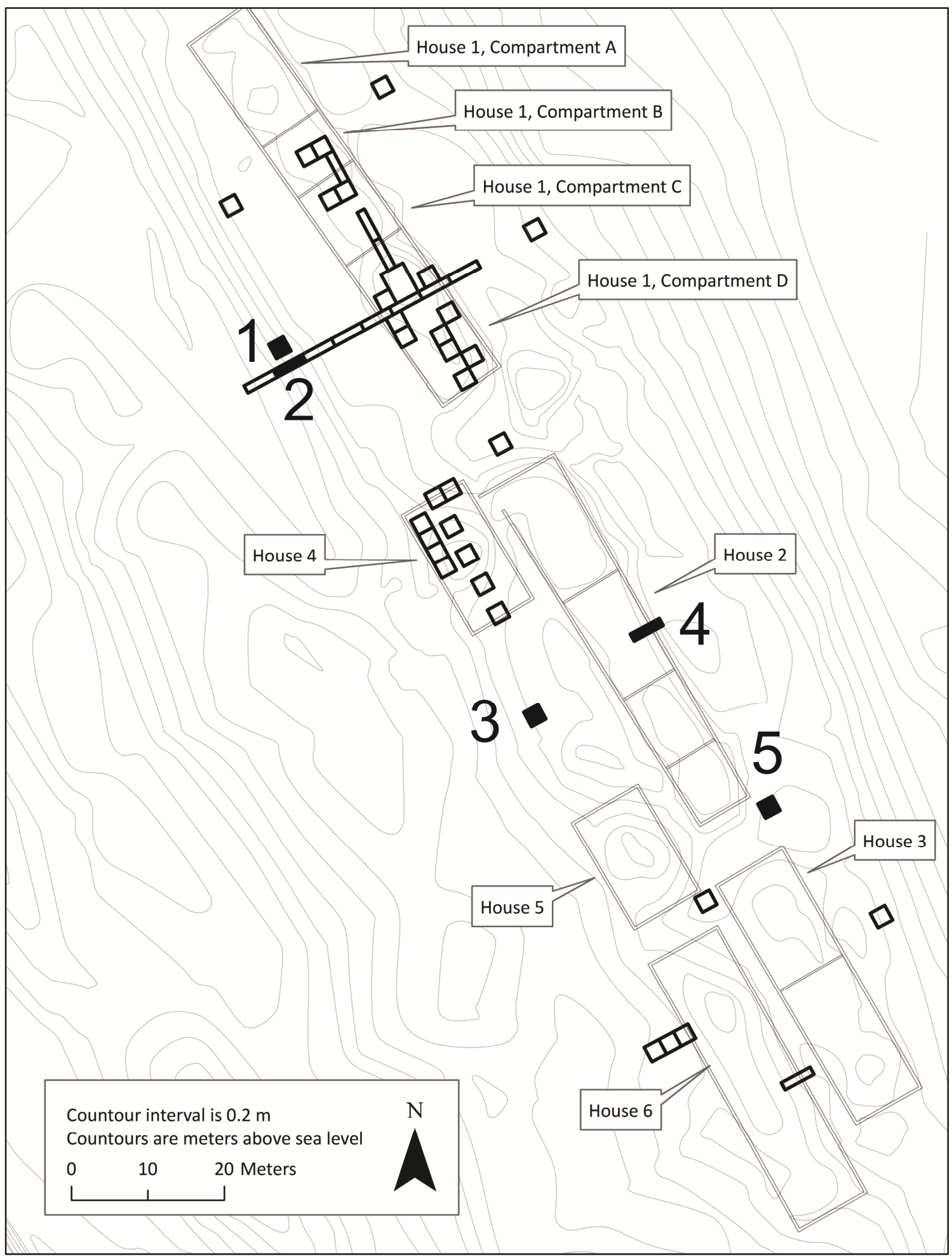



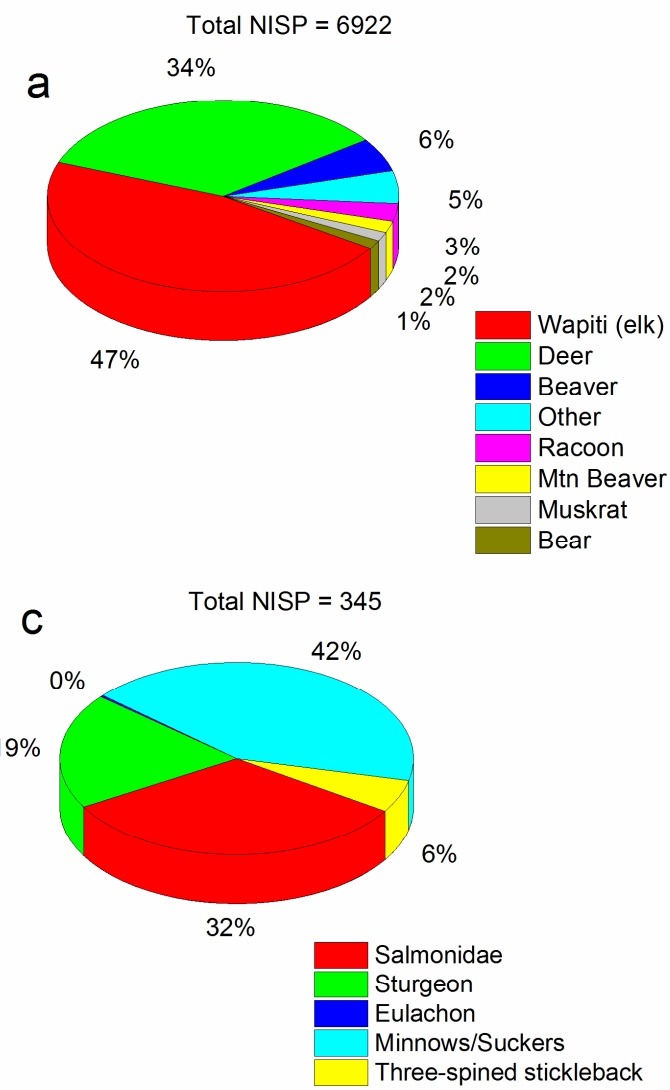

Total NISP $=470$
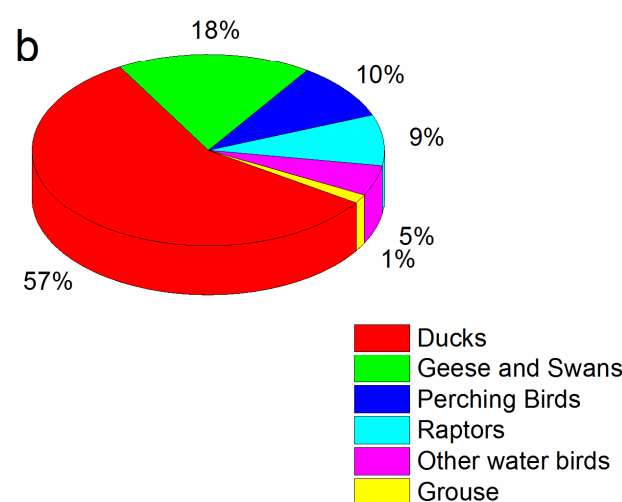

d Total NISP $=2474$

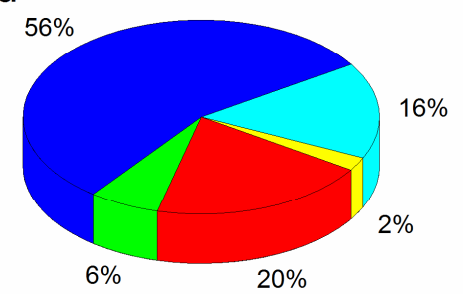

Salmonidae

Sturgeon

Eulachon

Minnows/Suckers

Three-spined stickleback 


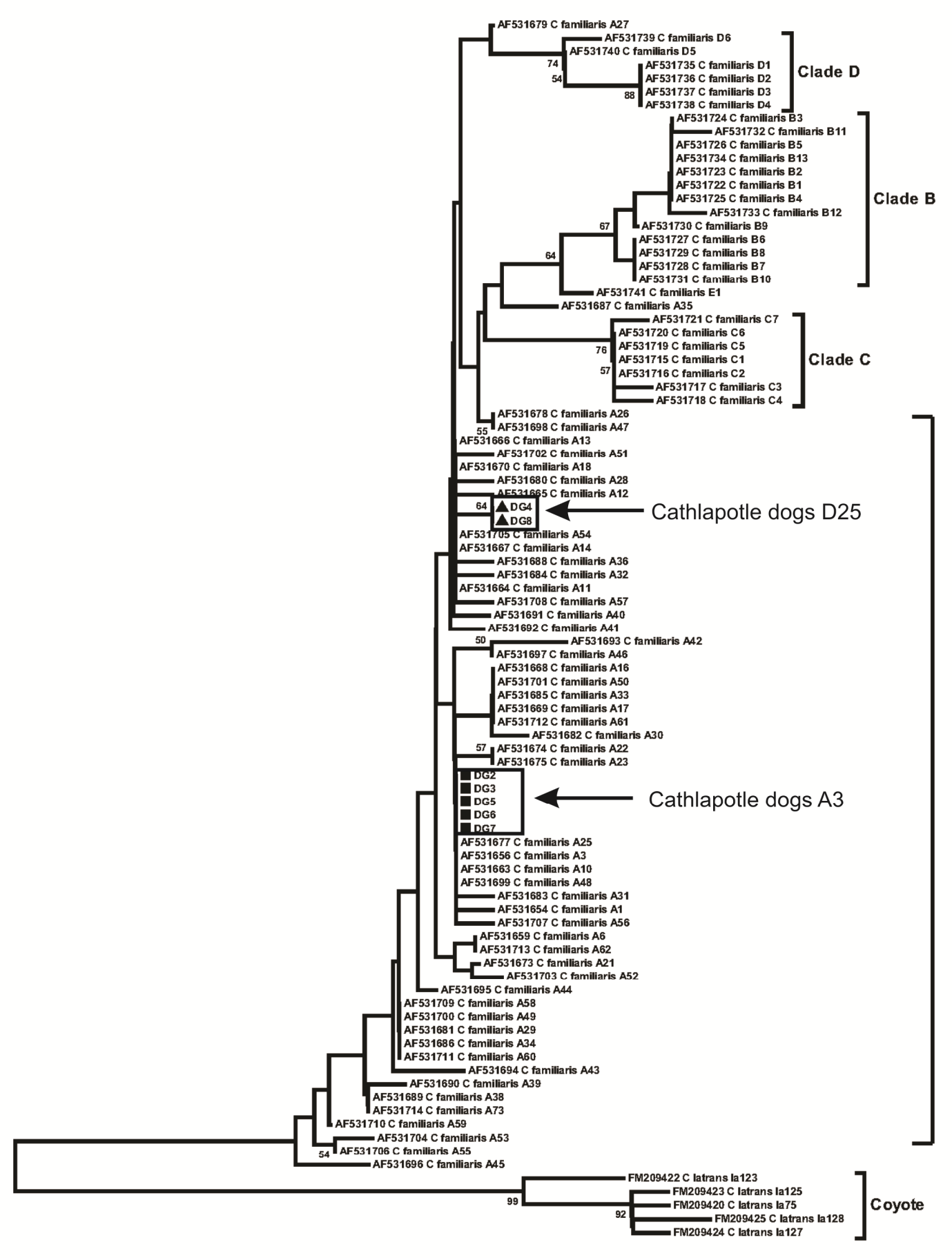

Clade A 


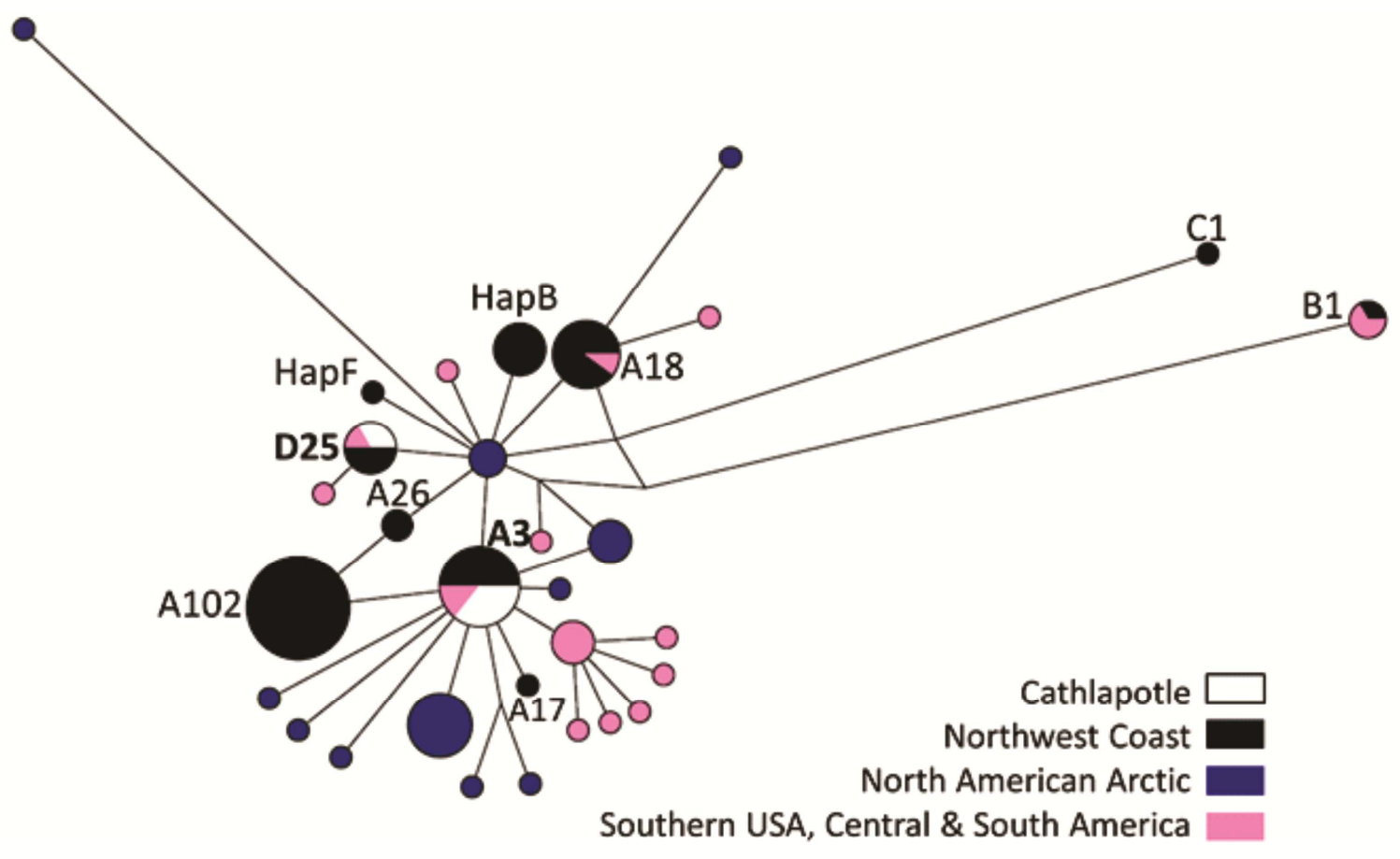


a

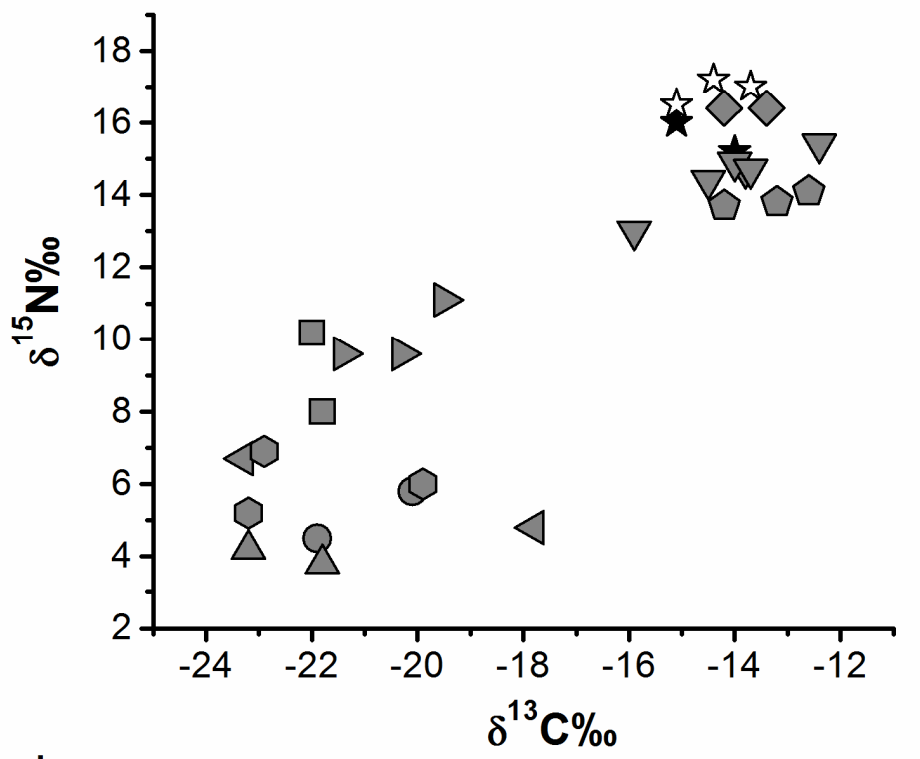

b

$\delta^{13} \mathrm{C} \%$

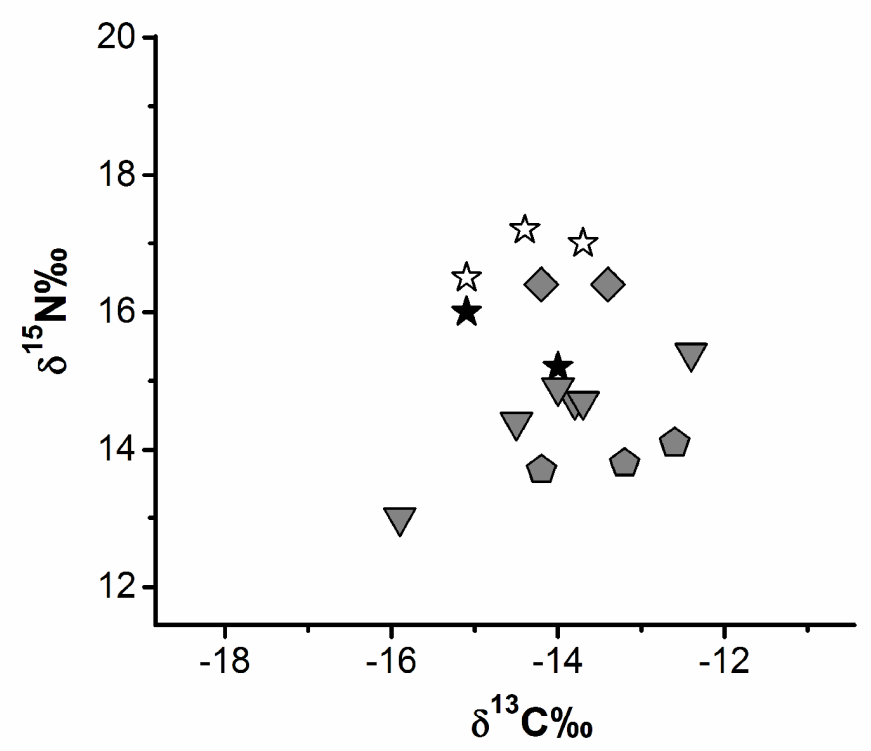

Black Bear

$\star$ Dog

- Eulachon

4 Mallard

$\checkmark$ Minnow

- Raccoon

$\checkmark$ Salmon

Sturgeon

- Sucker

$\triangle$ Wapiti 

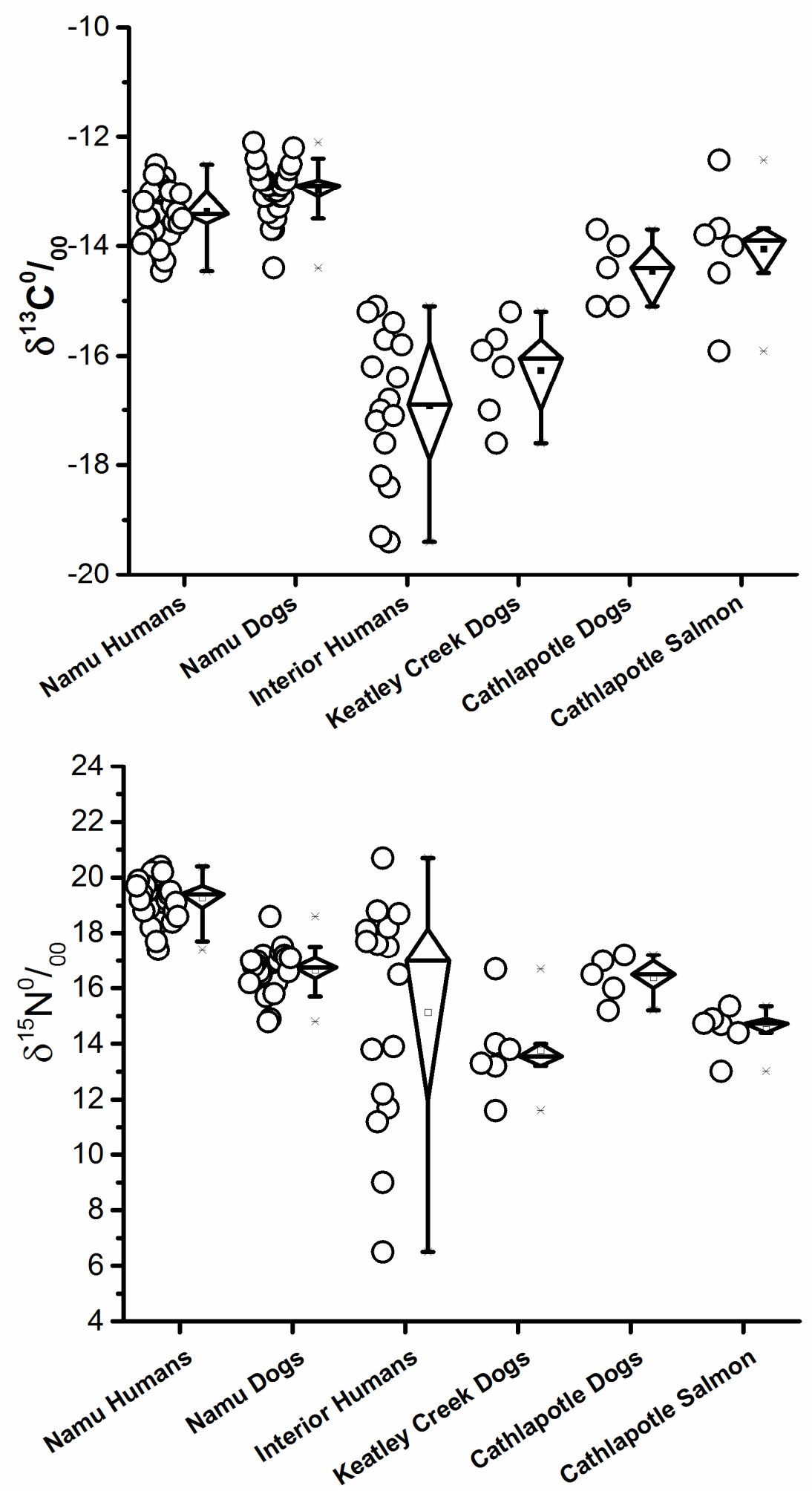
Ames et al. Stable isotope and aDNA analysis of dog remains from Cathlapotle

(45CL1), a contact-era site on the Lower Columbia River.

Highlights:

- aDNA and $\delta^{13} \mathrm{C}$ and $\delta^{15} \mathrm{~N}$ values from dogs from a fur-trade era site on the Lower Columba River were analyzed.

- Two haplotypes present among the dogs were patchily present to the north in British Columbia and at Teotihuacan in Mexico.

- Isotopic values indicated a completely marine diet despite ethnohistoric and zooarchaeological data indicating a mixed marine and terrestrial diet.

- The dogs were probably being fed eulachon, a smelt. 
Ames et al. Lower Columbia River Dogs, Revised Draft 2/10/2015 Supplemental Materials

Table S1. NISP of mammalian taxa represented at Cathlapotle (Lyman 2002). The "Other" category in Figure 4 includes the taxa with NISP less than 100. The total NISP for "Other" is 379.

\begin{tabular}{llc}
\hline Taxon & Common & NISP \\
\hline Cervus & Wapiti & 3224 \\
Odocoileus & Deer & 2376 \\
Castor & Beaver & 392 \\
Procyon & Raccoon & 207 \\
Aplodontia & Mtn. Beaver & 136 \\
Ondatra & Procupine & 106 \\
Ursus & Bear & 102 \\
Microtus & Mouse & 68 \\
Phoca & Seal & 65 \\
Lutra & River Otter & 64 \\
Lepus & Hare & 50 \\
Canis & Dogs & 39 \\
Mustela & Weasel & 29 \\
Lynx & Lynx & 26 \\
Felis & Mtn. Lion & 12 \\
Vulpes & Fox & 8 \\
Peromyscus & Deer mouse & 5 \\
Sorex & Shrew & 4 \\
Scapanus & Mole & 3 \\
Mephitis & Skunk & 3 \\
Martes & Martin & 2 \\
Ovis & Sheep & 1 \\
\hline Total & & 6922 \\
\hline
\end{tabular}


Ames et al. Lower Columbia River Dogs, Revised Draft 2/10/2015 Supplemental Materials

Table S2. NISP of avian taxa represented at Cathlapotle (Frederick 2009) used in Figure 4.

\begin{tabular}{|c|c|c|}
\hline Taxon & Common Name & $\begin{array}{c}\text { Cathlapotle } \\
\text { NISP }\end{array}$ \\
\hline \multicolumn{3}{|c|}{ Swans and Geese } \\
\hline Cygninae & Swans & 32 \\
\hline Anserinae & Geese & 52 \\
\hline \multicolumn{3}{|c|}{ Ducks } \\
\hline Anatinae & Dabbling Duck & 120 \\
\hline Aythyinae & Diving Duck & 26 \\
\hline Merginae & Mergansers & 7 \\
\hline $\begin{array}{c}\text { Duck, } \\
\text { Undistinquished }\end{array}$ & Duck & 117 \\
\hline \multicolumn{3}{|c|}{ Other Water Birds } \\
\hline Podicipedidae & Grebes & 1 \\
\hline Phalacrocoracidae & Cormorants & 4 \\
\hline Ardidae & Herons & 13 \\
\hline Gruidae & Cranes & 3 \\
\hline Laridae & Gulls & 2 \\
\hline Rallidae & $\begin{array}{l}\text { Rails, Gallinules and } \\
\text { Coots }\end{array}$ & 1 \\
\hline \multicolumn{3}{|c|}{ Raptors } \\
\hline Accipitridae & Hawks and Eagles & 32 \\
\hline Strigidae & Owls & 8 \\
\hline \multicolumn{3}{|c|}{ Grouse } \\
\hline Phasianidae & Grouse & 7 \\
\hline \multicolumn{3}{|c|}{ Perching Birds } \\
\hline Corvidae & $\begin{array}{l}\text { Jays, Magpies, } \\
\text { Crows }\end{array}$ & 31 \\
\hline Picidae & Woodpeckers & 6 \\
\hline Columbidae & Pigeons and Doves & 4 \\
\hline Muscicapidae & $\begin{array}{c}\text { Thrushes, Bluebirds } \\
\text { etc }\end{array}$ & 2 \\
\hline Emberizidae & Towhees, Sparrows & \\
\hline Icteridae & $\begin{array}{c}\text { etc } \\
\text { Blackbirds, Orioles }\end{array}$ & 1 \\
\hline & etc & 1 \\
\hline \multicolumn{2}{|c|}{ Total Identified Birds } & 470 \\
\hline
\end{tabular}


Ames et al. Lower Columbia River Dogs, Revised Draft 2/10/2015 Supplemental Materials

Table S3 NISP of Cathlapotle fish taxa recovered in 4 and $2 \mathrm{~mm}$ mesh from10 I bulk samples (Butler 2002) used in Figure 4.

\begin{tabular}{|c|c|c|c|c|c|}
\hline Taxon & $\begin{array}{l}\text { Common } \\
\text { Name }\end{array}$ & $>4 \mathrm{~mm}$ & $\%$ & $>2 \mathrm{~mm}$ & $\%$ \\
\hline Salmonidae & $\begin{array}{l}\text { Salmon, Trout, } \\
\text { Whitefish }\end{array}$ & 112 & 32.5 & 490 & 19.8 \\
\hline Acipenser sp. & Sturgeon & 67 & 19.4 & 158 & 6.4 \\
\hline Thaleichthys pacificus & Eulachon & 1 & 0.3 & 1374 & 55.5 \\
\hline Cyprinidae & Minnow & 56 & 16.2 & 83 & 3.4 \\
\hline Ptychocheilus oregonensis & $\begin{array}{c}\text { Northern } \\
\text { pikeminnow }\end{array}$ & 6 & 1.7 & 9 & 0.4 \\
\hline Mylocheilus caurinus & Peamouth & 5 & 1.4 & 10 & 0.4 \\
\hline Acrocheilus alutaceus & Chiselmouth & & & 2 & 0.1 \\
\hline Gila bicolor & Tui chub & & & 1 & 0.0 \\
\hline Rhinichthys osculus & Speckled dace & & & 1 & 0.0 \\
\hline Catostomidae & Sucker & 27 & 7.8 & 52 & 2.1 \\
\hline Catostomus macrocheilus & $\begin{array}{l}\text { Large scale } \\
\text { sucker }\end{array}$ & 1 & 0.3 & 2 & 0.1 \\
\hline Cyprinidae/Catostomidae & Minnow/Sucker & 51 & 14.8 & 236 & 9.5 \\
\hline Cottus sp. & Sculpin & & & 1 & 0.0 \\
\hline Gasterosteus aculeatus & $\begin{array}{l}\text { Three-spine } \\
\text { stickleback }\end{array}$ & 19 & 5.5 & 56 & 2.3 \\
\hline Total & & 345 & 100 & 2475 & 100 \\
\hline
\end{tabular}

